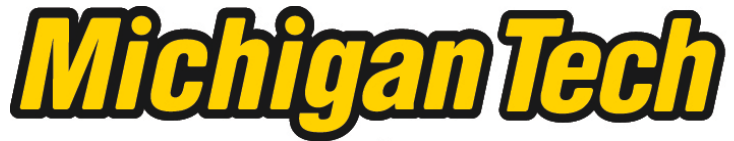 \\ Michigan Technological University Create the Future Digital Commons @ Michigan Tech
}

Peer influence in NIPF landowner decision making in the western Upper Peninsula, Michigan

Jillian R. Schubert

Michigan Technological University

Follow this and additional works at: https://digitalcommons.mtu.edu/etds

Part of the Environmental Policy Commons

Copyright 2011 Jillian R. Schubert

\section{Recommended Citation}

Schubert, Jillian R., "Peer influence in NIPF landowner decision making in the western Upper Peninsula, Michigan ", Master's Thesis, Michigan Technological University, 2011.

https://doi.org/10.37099/mtu.dc.etds/298

Follow this and additional works at: https://digitalcommons.mtu.edu/etds

Part of the Environmental Policy Commons 


\title{
PEER INFLUENCE IN NIPF LANDOWNER DECISION MAKING IN THE WESTERN UPPER PENINSULA, MICHIGAN
}

\section{By}

Jillian R. Schubert

\begin{abstract}
A THESIS
Submitted in partial fulfillment of the requirements for the degree of MASTER OF SCIENCE IN ENVIRONMENTAL POLICY
\end{abstract}

\section{MICHIGAN TECHNOLOGICAL UNIVERSITY \\ 2011}

(C) 2011 Jillian R. Schubert 
This thesis, "Peer Influence in NIPF Landowner Decision Making in the Western Upper Peninsula, Michigan," is hereby approved in partial fulfillment of the requirements for the Degree of MASTER OF SCIENCE IN ENVIRONMENTAL POLICY.

\author{
Department of Social Sciences
}

Signatures:

Thesis Advisor:

Dr. Audrey Mayer

Department Chair:

Dr. Patrick Martin

Date: 


\section{Table of Contents:}

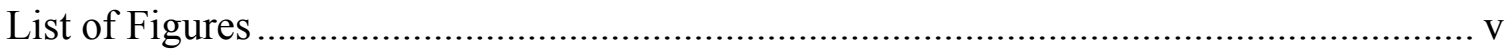

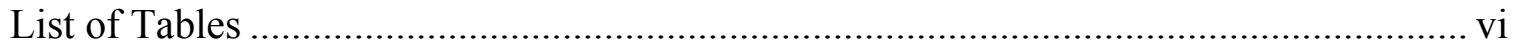

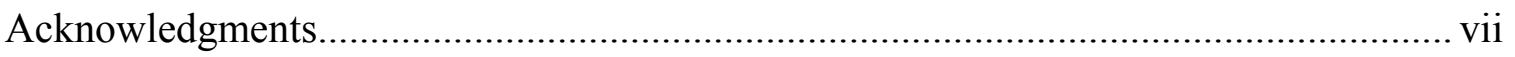

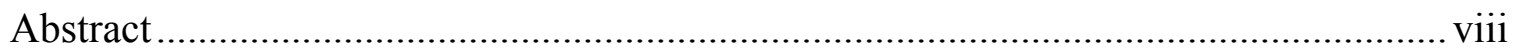

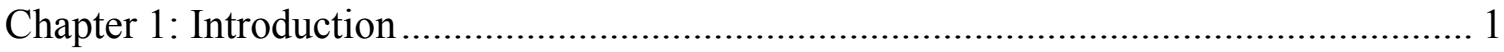

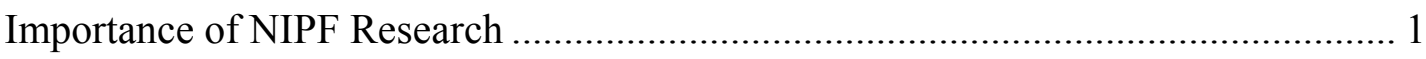

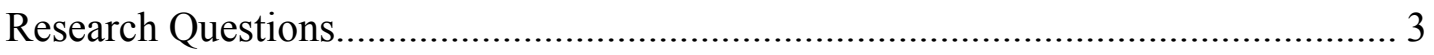

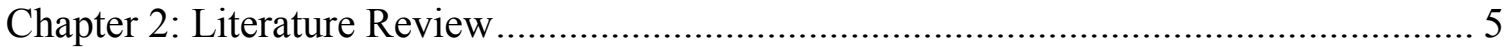

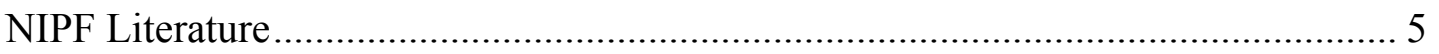

Policies and Programs for Private Forest Owners .............................................. 7

Commercial Forest Program …................................................................. 8

Qualified Forest Property ........................................................................ 8

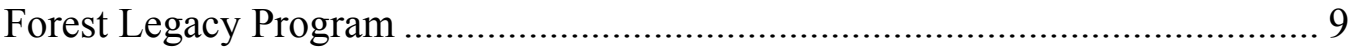

Environmental Quality Incentives Program ................................................. 10

Wildlife Habitat Incentives Program........................................................... 10

Conservation Stewardship Program ...................................................... 11

Forest Stewardship Program ............................................................. 11

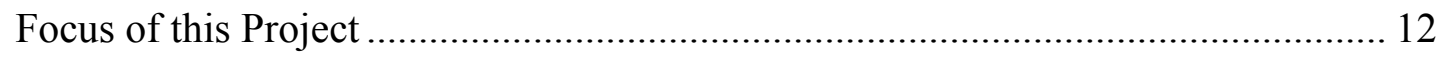

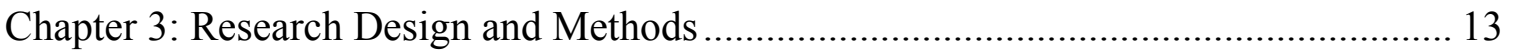

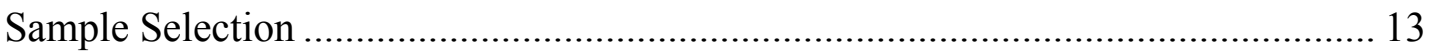

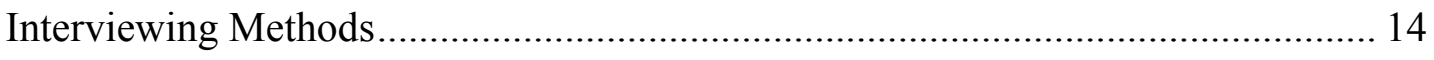

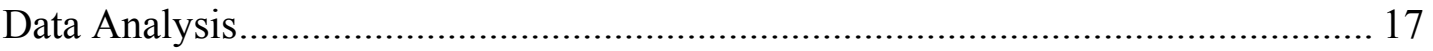




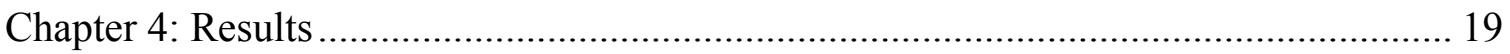

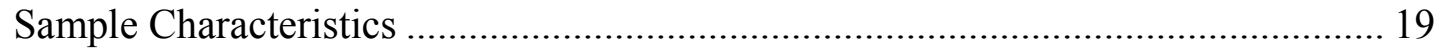

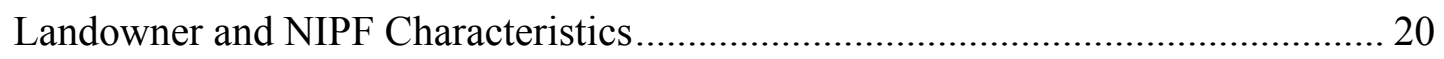

Owner Characteristics \& Forest Management............................................................. 22

Categorical test of owner characteristics and management ............................... 22

Regression test of owner characteristics and management ................................ 24

Neighbor Interaction and Management ............................................................... 27

Categorical test of neighbor influence ........................................................... 27

Regression test of neighbor influence ……………………............................ 29

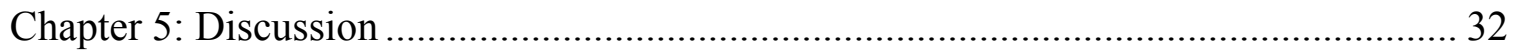

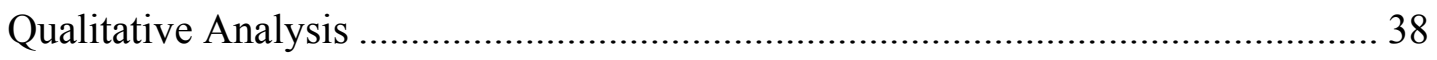

Privacy and Policy Impacts ........................................................................ 41

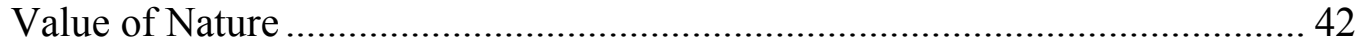

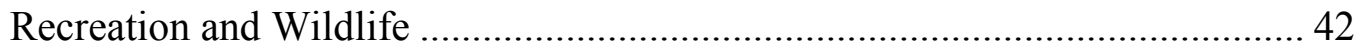

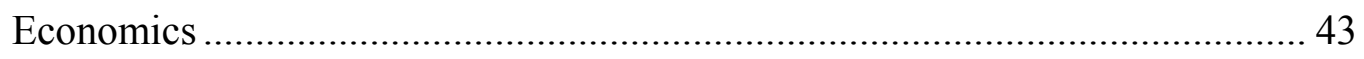

Governance and Program Participation.............................................................. 45

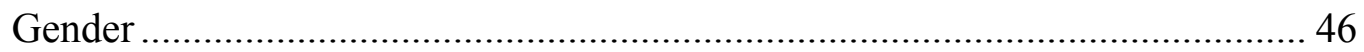

Qualitative vs. Quantitative Analysis .................................................................. 46

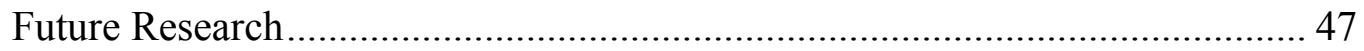

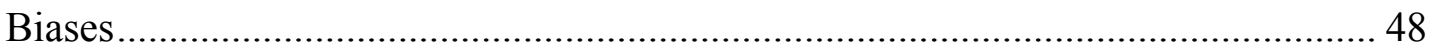

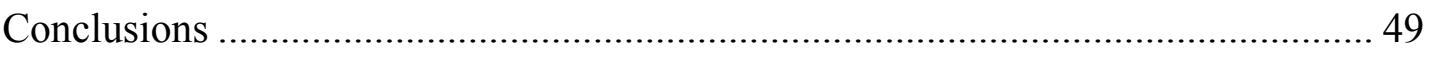

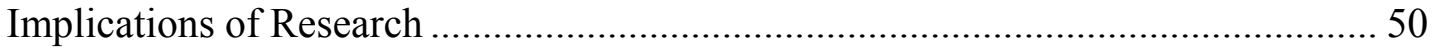

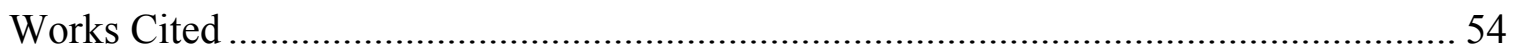

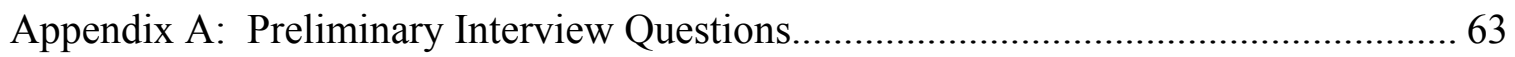

Appendix B. Main Sample Interview Questions …………….......................................... 65 


\section{List of Figures}

Figure 1.1 Western Upper Peninsula, Michigan Land Cover .............................................. 4

Figure 4.1. Number of Interviewees per County in the Western Upper Peninsula,

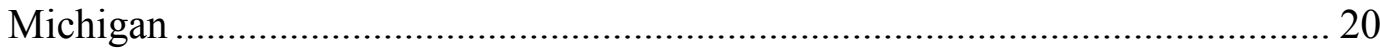




\section{List of Tables}

Table 4.1. Interviewees per community by county in the Western Upper Peninsula, Michigan

Table 4.2. Landowner and NIPF Property Characteristics for Preliminary and

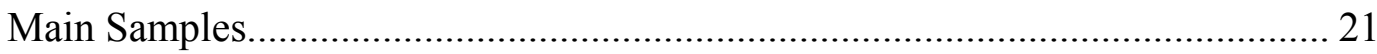

Table 4.3. T-test Results Comparing Preliminary and Main Sample Characteristics ...... 21

Table 4.4. P-Values from Pearson's Chi-Square Tests for Demographic Characteristics and Management Activities ............................................................................. 22

Table 4.5. P-Values from Second Run of Pearson's Chi-Square Tests

Table 4.6. P-Values from Regression Analysis of Demographic Characteristics and

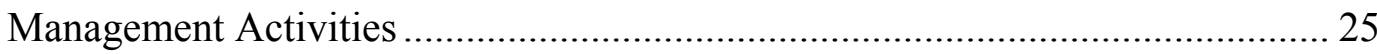

Table 4.7. P-Values from Second Run of

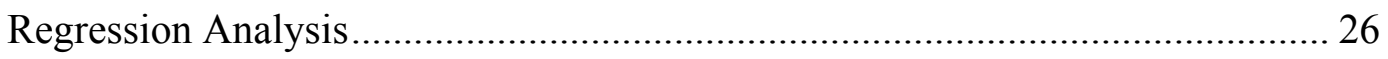

Table 4.8. Statistically significant results from Chi-square

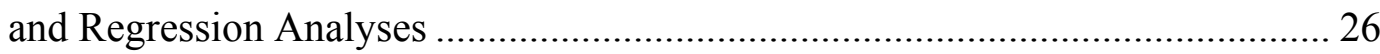

Table 4.9. P-Values from Pearson's Chi-Square Tests for Landowner and NIPF Characteristics and Neighbor Relationships ....................................................... 28

Table 4.10. P-Values from Second Run of Chi-Square Test .......................................... 28

Table 4.11. P-Values from Regression Analysis of Landowner and NIPF Characteristics

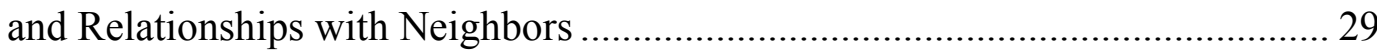

Table 4.12. P-Values for Second Run of Regression Analysis.......................................... 30

Table 4.13. Statistically Significant Results from Chi-square Analysis ............................ 30

Table 4.14. Summary of Significant Results and their Relationships .............................. 31 


\section{Acknowledgments}

I would like to thank my advisor, Dr. Audrey Mayer, for her guidance throughout my graduate studies and thesis research. I would also like to acknowledge and thank my committee members Dr. Carol MacLennan and Dr. Jennifer Daryl Slack for serving on my committee and providing valuable insights on my research.

I would also like to recognize my colleagues, family, and friends for their support. I especially want to recognize Brian Edwards for his assistance in using the statistical software and his love and support, my sister Brianna Stack for proofreading, and Callie Bertsch for helping me to prepare for the thesis defense. Finally, I want to thank my parents for their encouragement and constant confidence in me.

Last, but certainly not least, I would like to thank all of the landowners that participated in the study for generously donating their time. Their willingness to help was very much appreciated. 


\section{$\underline{\text { Abstract }}$}

Non-industrial private forest (NIPF) owners hold the largest amount of privately owned forest in the United States. Activities undertaken by NIPF owners have the potential to drastically impact the forested landscape of the United States, along with its associated biodiversity and ecological services. Many government sanctioned programs are in place to discourage the conversion of forest to other uses as well as to ensure sustainable management and a continuous supply of timber. Reaching NIPF owners with information about these programs and other management information is therefore important to the forests of the United States.

This thesis presents research on how the NIPF owners of the western Upper Peninsula of Michigan communicate about forest management with neighboring NIPF owners. The data were obtained from 34 telephone interviews with owners of NIPF properties in the western Upper Peninsula. The goal of this research was to understand the way information moves through NIPF owner dominated landscapes in order to provide recommendations to policy implementers on how to best reach NIPF owners with information. Understanding where NIPF owners get information about management and landowner assistance programs is vital to ensuring a sustainably managed forest landscape in the western Upper Peninsula of Michigan. 


\section{Chapter 1: Introduction}

According to the National Woodland Owner Survey there are 751 million acres of forested land in the United States, 56\% of which are owned by private entities (Forest Service 2008a). Private forest land can belong to one of many types of owners; timber companies and non-industrial private forest (NIPF) owners are two common types. NIPF land is private forest held by private entities which can include individuals and families, but also companies that do not own their own mills (Best and Wayburn 2001, Butler 2008). This project, however, will focus on familyowned NIPFs, and therefore "NIPF owners" refers to this family-owned subset. This type of owner holds $62 \%$ of privately owned forest area in the United States and comprises $92 \%$ of all private forest owners (Butler 2008).

NIPF owners are a demographically diverse group. In the U.S., the most common reason NIPF owners gave for owning forests was to have land for a residence ( $27 \%$ of owners), while the largest use of the land was timber production (Best and Wayburn 2001). The manner in which NIPFs are managed is likely to be very different among forest owners because of the wide variety in the size and intended use of properties. The diversity of NIPF owners and their goals makes it difficult to know where they are getting their information about how to manage their land, especially considering that only $4 \%$ of NIPF owners have a written management plan (Butler 2008). However, according to the National Woodland Owner Survey, $40 \%$ of NIPF land is owned by people who have had some kind of guidance about how to manage their land, although they may not have a written plan (Forest Service 2008a).

\section{Importance of NIPF Research}

One of the reasons that NIPF landowners are studied so often is the potential ecological impact they are capable of having. Fragmentation is a widespread risk of individual-based decision-making in private forest ownership (Best and Wayburn 2001, Mehmood and Zhang 2001, Erickson et al. 2002, Gustafson and Loehle 2006). Forest fragmentation occurs when segments of a larger forest landscape are cleared 
to make way for development or other land use, leaving the remaining forest in small patches distributed throughout the landscape (Saunders et al. 1991).

Fragmentation can have many implications that are damaging to wildlife; even small habitat losses added to the amount that has already been lost can critically impair wildlife populations (Schmiegelow and Mönkkönen 2002, Swift and Hannon 2010). Some species may be reluctant to use areas with human presence and change their behavior to avoid humans in their territories (Quinn 1997, McClennen et al. 2001). The isolation of fragments from one another is also important; isolation prevents populations from interacting with one another and can cause problems with genetics, population dynamics, and ultimately risk of species extinction. Isolation also contributes to the decline of species diversity in the patches; some species no longer have large areas to gather resources from, and when they are isolated, there is no way for them to move from fragment to fragment while remaining in the forest's protective cover (Bennett 2003, Swift and Hannon 2010).

Land use change is predicted to have the largest impact on biodiversity in the next century (Chapin et al. 2000). Forest conversion destroys habitat, while parcelization and the subsequent increase in the rural human population can endanger wildlife and change the species composition of an area (Wilcove et al. 1998, Hansen et al. 2005). When habitat is lost, species are driven to the edge of their ranges where survival is more difficult (Chapin et al. 2000). Overall, land conversion from forest decreases habitat, reduces access to resources, and causes isolation of populations. All of these contribute to a decline in biodiversity.

Good management practices and prevention of forest conversion on NIPFs is vital to maintaining biodiversity and ecosystem services. Over half of the listed endangered and threatened species in the United States depend on private property (Irland 1994, Creighton et al. 2002). The activities undertaken by NIPF owners can help determine species' continued existence or extinction. 


\section{Research Questions}

There are approximately 30,000 NIPF owners in the western Upper Peninsula and they control 3,011,000 acres (Butler 2010). The western Upper Peninsula has a lower than average proportion of NIPF land than the United States as a whole, but the same trends of increasingly non-rural landowners and landscape fragmentation are present. The area is approximately $81 \%$ forested (Figure 1.1); sustainable management and prevention of forest loss is vital in this area, not only for preservation of various forest types and wetlands, but for the region's propensity to host breeding songbirds and other wildlife (Michigan DNR 2005). Increasing amounts of privately held land are being sold and developed; corporations sold more than one million acres of Upper Peninsula forestlands in 2005-2006 alone (Froese et al. 2007).

Many new NIPF owners live a significant distance from their forest land, which could have an effect on their relationship with neighboring forest owners. The way one landowner manages their property may impact surrounding forest management. In New England, Rickenbach and Kittredge (2009) found that both the length of time a landowner has possessed the NIPF land and the distance they live from it (particularly if they have also owned it for a short time) impacts the relationship they have with their neighboring landowners. However, unlike other influences on management, peer influence has not been studied extensively in the United States (West et al. 1988).

This project seeks to answer the following questions:

\#1. Are the management decisions of NIPF land owners in the western Upper Peninsula of Michigan influenced by their neighbors?

\#2. If neighbors are influencing each other's management, is it indirectly (through observations of management) or directly (through conversations about management or referrals to sources of advice)?

Along with these two questions, I plan to look at different characteristics of the landowners and observe whether or not certain characteristics seem to impact the influence of neighboring landowners. The western Upper Peninsula is of 
particular interest to me because of the lack of information regarding this area. Michigan as a whole, as well as the eastern part of the Upper Peninsula, however, have significantly more research available on private forest owners (e.g. Beyer et al. 1997, Leatherberry et al. 1998, Potter-Witter 2005).

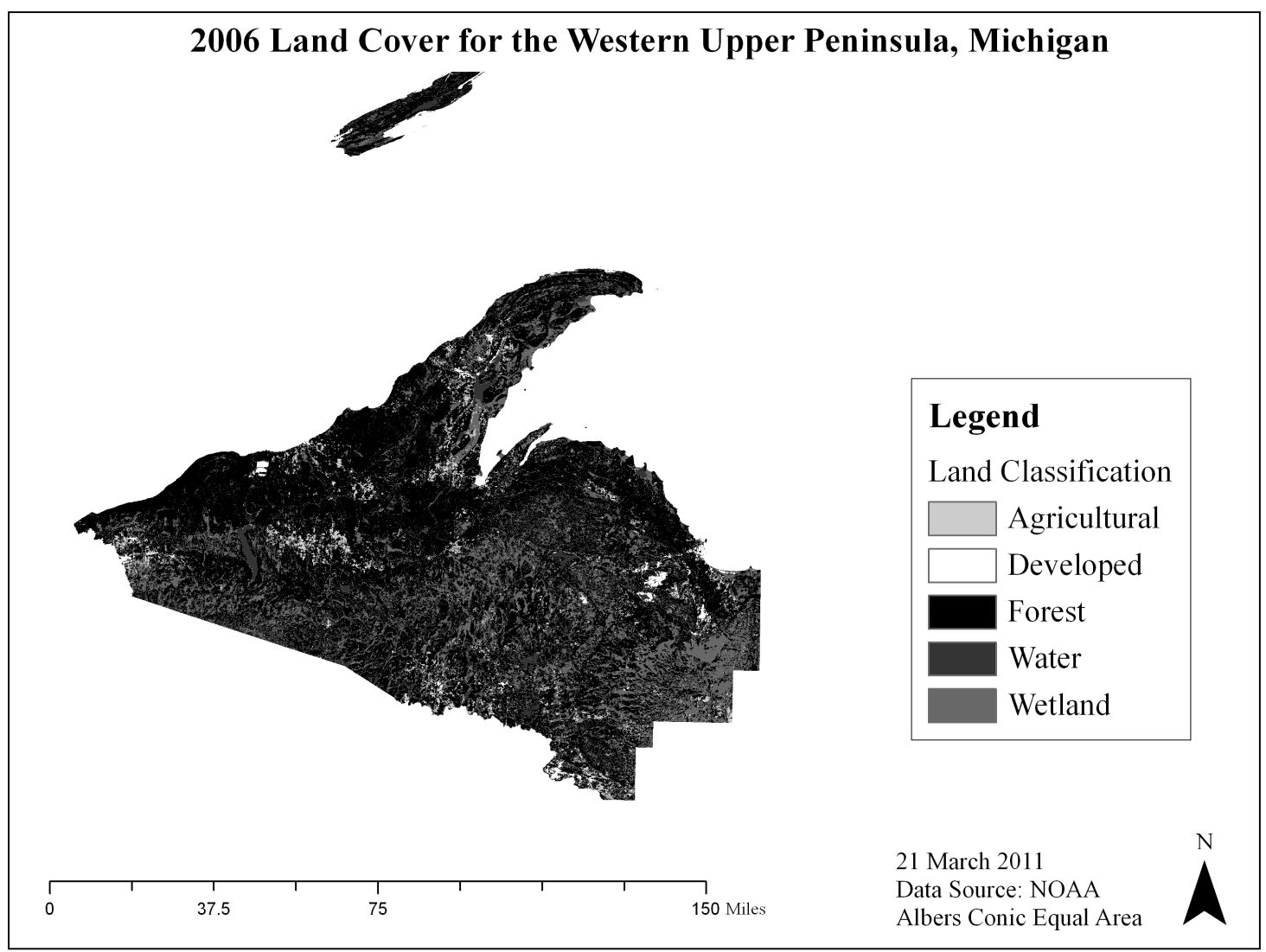

Figure 1.1. Western Upper Peninsula, Michigan Land Cover. 


\section{Chapter 2: Literature Review}

\section{NIPF Literature}

There is currently a large amount of published research regarding NIPF owner demographics as factors contributing to their management decisions (Hodgdon et al. 2007). However, NIPF ownership has been changing; forest products companies have subdivided and sold large tracts of land, making it possible for many more people to own NIPF land (Mehmood and Zhang 2001, Gustafson and Loehle 2008). Many new NIPF owners either do not live on their forested lands, or are recent transplants from urban areas (Jones et al. 1995). These new, non-rural owners are thought to have mostly non-economic motivations for owning land (Erickson et al. 2002). Their management motivations may be more difficult to decipher than if they were just interested in timber. NIPF ownership is also changing through the turnover of land by older generations to their non-rural descendants. Nationally, sale or transfer of forest land to another owner is expected by $14 \%$ of landowners from 2008 to 2013 (Forest Service 2008b). Knowing NIPF owners' motivations for management choices is important in order to design policies to promote sustainable management.

Several studies have found significant relationships between demographic factors and management decisions (Amacher et al. 2003, Beach et al. 2005, Joshi and Arano 2009). Many found that higher income landowners were less likely to manage for timber harvests, possibly because they do not see their forest land as a source of income (Loyland et al. 1995, Joshi and Arano 2009). Previous research has also typically found age to be negatively correlated with timber harvest (Kuuluvainen et al. 1995, Beach et al. 2005). Newer landowners, in general, have a higher level of education and income and a lower average age (Jones et al. 1995, Erickson et al. 2002). This suggests that newer owners, many of whom are more wealthy, younger (if inheritors), and non-residents of their property, will be less likely to manage for timber. Based on the fact that they live far away or recently 
moved to their land, this could imply that they do not manage in a similar fashion as long-time owners because they are less influenced by their neighbors.

As for making management decisions based on their neighbors' management practices, more landowners nationwide cited state forestry agencies and private consultants as the primary sources of advice (Forest Service 2008a). However, one study found that advice from neighbors and family members may have been applied to management more often than information received from other sources (West et al. 1988). Landowners will sometimes make decisions based on perceived results of neighbors' management without actually asking directly for advice (Rickenbach et al. 2005). This suggests that landowners may prefer formal advice from professionals in the natural resources industry, but that they are still influenced informally by seeing how management practices work on neighboring properties.

Other factors that impact relationships, and most likely communication, with neighbors include the land tenure and the distance of their primary residence from the NIPF property. Rickenbach and Kittredge (2009) examined the average number of neighbors landowners knew, and then found that long term owners of NIPF land, as well as those residing nearby, knew more neighbors than owners that recently acquired NIPF land or that lived far away from it.

The reasoning behind the propensity of landowners to follow in their neighbors' or an opinion leader's footsteps has been researched as well; the ideas of social norms and social influence are major factors in human behavior. Opinion leaders are an important factor regarding peer influenced management choices. An opinion leader is defined as a person well respected by their community and often holding a local leadership position; most importantly, they are thought of as good land managers (Rogers and Schoemaker 1971). Opinion leaders are thought to be innovative and influential, which could lead to many of their surrounding landowners adopting the practices they advocate (Haymond 1988). Social norms are generally accepted practices and behaviors in a community or culture that influence individual behaviors, while social influence is when a majority pressures a minority to conform to a certain behavior (Cialdini et al. 1998). These forces are at 
work in NIPF management decision making; peer influence can have a greater effect on management than advice and information from forestry professionals (West et al. 1988).

According to the National Woodland Owner Survey, more Michigan NIPF owners get advice and management information from federal agencies or private consultants than from other sources (Forest Service 2008a). "Other forest owners" were the management advice sources for approximately $9.7 \%$ of Michigan NIPF owners surveyed (Forest Service 2008a). Approximately 68\% of Michigan NIPF owners consider their NIPF land to be their primary residence (Forest Service 2008a). In Michigan, a substantial proportion of owners have inherited property and $18.0 \%$ do not consider it a primary residence, while $21.3 \%$ do not consider it a primary or secondary residence (Forest Service 2008a). The number of owners who do not reside on their forest land has increased significantly in the Upper Peninsula; the number of owners living one hundred miles or more from their timberland has increased by 31\% from 1981 to 1994 (Leatherberry et al. 1998, Potter-Witter 2005). The research on Michigan and, more specifically, the Upper Peninsula, NIPFs reflects the trend of more urban NIPF landowners residing far from their NIPF.

\section{Policies and Programs for Private Forest Owners}

The state of Michigan has the $13^{\text {th }}$ largest area of NIPF land in the United States (Butler 2008). Michigan has several state and federal-level programs in place for NIPF and other private forest owners. Many of these programs were put in place to prevent the loss of forest and the aforementioned ecological impacts that can accompany deforestation. Often, landowner assistance programs require certified management plans to ensure that only good management practices are used on participating NIPFs. Knowing the requirements and benefits of programs available to Michigan NIPF owners can be useful in understanding why forest owners participate in certain types of management. Since the programs have a variety of objectives and benefits, the programs that a landowner chooses to participate in may also give clues as to what that landowner values about their land. I believe my research will benefit these programs by showing 
where landowners get management information and where information is lacking. If the goal of these programs is in fact to protect the timber supply and forest resources of the United States, it will be beneficial for the administrators of the programs to be aware of landowners' preferences and methods for acquiring management information.

\section{Commercial Forest Program}

The Commercial Forest program requires participants to maintain forest on their property and to continuously manage the forest for timber (DNR 2011a). Landowners are also required to open enlisted lands to non-motorized public access for hunting, trapping, and fishing (DNR 2008). This program ensures that Michigan residents have access to recreational lands and that Michigan has a continuous timber supply from private forests.

There are a few major prerequisites to enroll in the Commercial Forest program. The first requirement is that there be at least forty adjoining acres (DNR 2008). Landowners must also develop a management plan with a registered forester; the plan must specify actions to be taken on the forest as well as a timeline of when management actions should be undertaken. In return for enrolling in the Commercial Forest program, landowners pay the reduced property tax rate of $\$ 1.20$ per acre enrolled (DNR 2008). Counties also receive $\$ 1.20$ per acre from the state of Michigan for each acre within the county that is enrolled. The Commercial Forest program was the most popular program with interviewees and has 2.2 million acres and almost 1700 private landowners enrolled (DNR 2011a).

\section{Qualified Forest Property}

Michigan's Qualified Forest Property program is designed to promote active management of private forests (DNR 2011b). The program is somewhat similar to the Commercial Forest program. Landowners enrolled in the Qualified Forest Property program also receive a tax break, but it is through an exemption from selected taxes for schools (Potter-Witter 2008). While the tax break is not as beneficial to landowners as that given by the Commercial Forest Program, the requirements are less stringent. In 
order to enroll in the Qualified Forest Property program, landowners only need 20 contiguous acres with no structures (Potter-Witter 2008, DNR 2011b). There is a cap of 320 acres that can be enrolled per taxing unit, and of 900,000 total acres in the program (DNR 2011b). The enrolled land must have an approved management plan for at least $80 \%$ of the total acreage (Potter-Witter 2008, DNR 2011b).

\section{Forest Legacy Program}

In addition to the programs that are exclusive to the state of Michigan, there are also several programs funded by the federal government. Many of these programs were put into place through various Farm Bills. The first Farm Bill was enacted in 1933 (Dimitri et al 2005). It was not until the 1990 Farm Bill, or Food, Agriculture, Conservation, and Trade Act that many assistance programs intended for forest owners were included (Food, Agriculture, Conservation and Trade Act 1990, Schaaf \& Broussard 2006). One such program is the Forest Legacy program. The Forest Legacy program is a cooperative effort between the federal and state governments that is in place to protect "environmentally sensitive forest lands" (Forest Service 2008c). The program is implemented at the state level and the federal government contributes by supplying a maximum of $75 \%$ of costs (Forest Service 2008c, DNR 2011c). It is a voluntary program that encourages private forest owners to enter into conservation easements so that their land is protected from development and managed sustainably (DNR 2011c). In order to enroll in the program, landowners must obtain a management plan and the state must be given the right of public access (DNR 2011c). In giving up rights to the land, owners are essentially selling part of their land to the program, so they receive payment for these rights (Forest Service 2008c). Because the value of land diminishes when the owners enter into an easement, they often also receive benefits in the form of reduced taxes (Forest Service 2008c). Since the program began, Michigan has eight tracts in the Forest Legacy Program totaling 151,351 acres (Forest Service 2011). 


\section{Environmental Quality Incentives Program}

Another program created by the Farm Bill is the Environmental Quality Incentives Program, or EQIP. This program was enacted with the 1996 Farm Bill (Federal Agricultural Improvement and Reform Act 1996, Womach 2005). While it is a federally funded program, each state decides how to allocate funds within the state and passes implementation responsibilities to local Natural Resources Conservation Service (NRCS) conservationists (NRCS 2009). EQIP was created to help agricultural, tribal, and private forest owners to follow environmental regulations while continuing crop production (NRCS 2011a). As it is a part of the Farm Bill, the majority of the funding for the program is set aside for livestock farming (Womach 2005, Gray and Teels 2006). The program does, however, provide resources to forest owners as well, as timber can be considered a crop. The Environmental Quality Incentives program assists landowners through financial, technical, and educational resources (NRCS 2011a). In order to receive EQIP assistance, forest owners must be producing timber and have a management plan approved by the NRCS or the Michigan DNR (NRCS 2011a). Assistance is given to private forest owners through a cost-share program; the NRCS covers a portion of the typical cost to implement conservation measures (NRCS 2011a). Each private forest owner enters into a contract with the NRCS for one year to ten years, and can receive no more than $\$ 300,000$ in assistance over a six year period (NRCS 2011a).

\section{Wildlife Habitat Incentives Program}

The Wildlife Habitat Incentives Program (WHIP) was also created with the 1996 Farm Bill (Nelson and Schertz 1996). WHIP, like EQIP, is a cost-sharing program run by the NRCS (Federal Agricultural Improvement and Reform Act 1996, Nelson and Schertz 1996). It was established to encourage NIPF, tribal, and agricultural landowners to improve wildlife habitat on their land (Nelson and Schertz 1996). In order to do this, the NRCS provides technical resources and financial assistance of up to $75 \%$ of the cost of a project (NRCS 2010a). Landowners enrolled in WHIP can receive no more than $\$ 50,000$ in assistance per year and cannot be enrolled in any other federal cost-share program (NRCS 2011b). WHIP is being used in Michigan to resolve priority threats to 
wildlife identified by the state, including invasive species, fragmentation, riparian modifications, and altered fire regimes (NRCS 2006).

\section{Conservation Stewardship Program}

The Conservation Stewardship Program (CSP) was authorized through the 2008 Food, Conservation, and Energy Act (Farm Bill). It replaced the Conservation Security Program from the 2002 Farm Bill (ERS 2008). Like all of the previously mentioned Farm Bill programs, the CSP is completely voluntary. The goal of the CSP is to encourage landowners to improve conservation measures on their land; enrollment in CSP is not limited to agricultural, tribal, and NIPF land, but is also extended to grasslands, prairies, improved pastures, and rangeland (NRCS 2010b). It provides both technical and financial assistance to landowners to aid them in introducing, upgrading, and maintaining conservation measures (NRCS 2010b). Participants in the CSP receive payment based on how well their conservation measures worked, up to $\$ 200,000$ every five years (Johnson et al 2008, NRCS 2010b). While the program is run by the NRCS, like WHIP, the state is given responsibility for choosing priorities on which to focus their efforts (NRCS 2010c). Michigan's current priorities include: air quality, animals, plants, soil erosion, and water quality (NRCS 2010c). The CSP's goal is to enroll at least 13 million acres throughout the U.S. into the program each year (Johnson et al 2008).

\section{Forest Stewardship Program}

The Cooperative Forestry Assistance Act of 1978 preceded much of the Farm Bill legislation providing for forest owner assistance. This act created several programs specifically for forest owners. One such program is the Forest Stewardship Program (Cooperative Forestry Assistance Act 1978). The main goal of this program is to help NIPF owners to better manage their land (Forest Service 2010). This program is mandated by the federal government but run at the state level. Each state has its own program, but must follow national guidelines regarding the focus of the program. The national objectives include: conserving working forest lands, protecting forests from threats (such as natural disasters, diseases, or insect outbreaks), and enhancing public 
benefits from forests (Forest Service 2009). There is no financial assistance with the Forest Stewardship Program; landowners who participate receive information and technical assistance to sustainably manage their land (Forest Service 2009). However, because it is not free to obtain a management plan as required by the program, the Michigan DNR does have financial assistance for that aspect of the program (DNR 2011d). In order to be eligible to participate in the Forest Stewardship Program, landowners must have an approved management plan and must abide by it (Forest Service 2009).

While there are several programs in place to aid NIPF owners, many of these programs are not directly targeted to NIPF owners. Many programs are primarily for agricultural lands, but can be utilized by NIPFs as well. It was difficult to find information on many of the programs and many of the government websites have not been updated to reflect changes in recent bills that led some programs to be eliminated.

\section{Focus of this Project}

My research examines whether or not neighboring landowners influence NIPF management and whether this influence is direct or indirect. I focus on characteristics of landowners that have previously been researched (tenure, distance of primary residence from property, and demographics) and how they affect the way a landowner is influenced by neighbors, if at all. I hypothesize that some NIPF owners are influenced by their neighboring landowners and that both indirect and direct influence occurs. My research will determine if forest owners impact each other's management and how management information moves through forest owner communities. My research will fill gaps in the NIPF literature on owners' interaction and contribute to the growing body of knowledge on NIPFs. It may also help improve the participation rates of NIPFs in management and conservation programs by highlighting how information about these programs can be more effectively distributed throughout the NIPF owner community. 


\section{Chapter 3: Research Design and Methods}

\section{Sample Selection}

I addressed my research questions through interviews ${ }^{1}$ with NIPF owners in the western Upper Peninsula. I identified potential interviewees using plat books for the western eight counties of the Upper Peninsula, including Gogebic, Ontonagon, Houghton, Keweenaw, Baraga, Iron, Marquette, and Dickinson County. I randomly chose areas that appeared to have clusters of NIPF owners using the information on the plat map. I compared the plat maps to recent LANDSAT satellite imagery to make sure these areas were actually forested.

For the preliminary interviews I conducted in the summer of 2010 (Appendix A), I used a different method of choosing landowners than I did for my main sample. For each area, I randomly picked one landowner to call and an alternate landowner in case the first was not interested in being interviewed. I chose approximately three forest owner communities per county. After setting up an interview with a landowner in a neighborhood of NIPFs, I asked them to recommend neighbors that might be willing to be interviewed as well, and so on. This method is known as snowballing. In previous studies, snowballing has been used to make sure a large range of ideas were included, to interview as many group members as possible in order to better characterize the group overall, and to locate populations that cannot be randomly sampled because there is no list of members (Rickenbach and Reed 2002, Gan et al. 2003, Schaaf et al. 2004). I used this method because I had hoped it would also shed additional light on who landowners communicate with most often, based on whom the landowners recommended for additional interviews. After conducting preliminary interviews, I found that the snowballing method was not particularly effective. Only four neighbors were recommended and only one of these agreed to do an interview and recommended a neighbor; the neighbor that he recommended was the person who had recommended him. This did not enable me

\footnotetext{
${ }^{1}$ The protocol for my Institutional Review Board is approval \#M0607.
} 
to reach as many communities of NIPF owners as I had hoped. As a result, I had very few interviewees from the same community. To better understand the dynamics of the landowner communities, I changed my methods for my main sample. Instead of choosing one landowner to call and another as a backup from each community, I randomly chose communities as I did before, but attempted to obtain the phone numbers for as many people in the community as possible. I called each person with a phone number listed and attempted to interview them all. This tactic made recommendations less necessary, but I continued to ask for recommendations because it gave me an idea of who the interviewees communicated with in the community. Snowballing also continued to be helpful because the area that I considered a community was loosely defined and interviewees recommended people that I had not considered to be their neighbors. This was especially true if the interviewees owned more than one NIPF property; I may have found their property in one area in the plat book, but they recommended the neighbors of their other property. Although I changed tactics in order to be able to speak to entire communities, the problem of unlisted phone numbers still existed. Even when the contact information was available for multiple landowners in a community, many of the landowners did not want to participate.

\section{Interviewing Methods}

The interviews were semi-structured and consisted of a mix of close and open-ended questions. Most of the questions for my main sample were open-ended (Appendix B). However, the preliminary sample consisted of mostly close-ended questions, which resulted in very short, non-descriptive answers. By using an openended interview instead of a survey or close-ended interview, informants were able to elaborate on their answers and therefore factors that would not be considered in a survey can be addressed (Bliss and Martin 1989). According to Bliss and Martin (1989), "qualitative methods are more effective for discovering the relationships between beliefs, attitudes, and behavior, and for identifying parameters of importance". 
I conducted the preliminary interviews via telephone or e-mail, while the main sample consisted of only telephone interviews. While some were done via email, I still conducted the majority of the interviews by telephone. For those preliminary interviews in which e-mail was used, I first contacted the interviewees by telephone. I only conducted interviews via e-mail if the landowner requested to participate in this way, due to time constraints or other issues. This method was abandoned after the preliminary sampling had concluded because many landowners forgot to respond to the e-mail and e-mailing resulted in less data due to the lack of possibilities for follow up questions. I chose to use mostly telephone interviews rather than in person interviews for several reasons. First, telephone interviews are more cost-effective than face to face interviews (Babbie 2010). Because my study area encompasses several counties (many of the people that I called for an interview lived hundreds of miles from where I am located), arranging meetings and traveling to meet with each interviewee would be expensive and time-consuming. Another reason that phone interviews are commonly used in place of in-person interviews is for the safety of the researcher (Dillman 1978, Babbie 2010).

When conducting the interviews, the first step I took was to contact the interviewees. I began by explaining the nature of the project. I then asked if they would be willing to participate in a telephone interview and, if so, they scheduled an interview time. During the interview, I took detailed notes of what the interviewees were saying. I typically explained to the interviewees at the beginning of the interview that any pauses in my questioning were due to the fact that I was taking notes on their responses. I attempted to record everything that the interviewees said during the interview by using shorthand. While the questions were open-ended, the responses given by the majority of the landowners were not particularly detailed, making it easier to record quickly. At the end of the interview, I immediately typed up my thoughts and impressions about the interview along with any information that I did not manage to capture in my notes during the interview. The interview questions and notes from the interview were then also typed up so that I would not forget any abbreviations or shorthand that I had used. 
I used detailed field notes to record the data from my interviews instead of the more commonly used tape or electronic recording for several reasons. Despite the fact that the interviews did not contain a lot of personal questions, according to Lee and Renzetti (1990) and Corbin and Morse (2003), any topic could be considered sensitive depending on the interviewee. The interviews that I conducted are more likely to be considered sensitive than much of the previous NIPF research because I asked questions about neighboring landowners and interviewees' opinions of neighboring landowners' management. Some researchers believe recording interviews causes participants to censor their opinions, which biases data, although very little actual research has been done on the subject and tape recording seems to have been accepted without much question (Lee 2004). Another reason I chose not to record phone interviews was to obtain the largest sample possible. Because I called landowners without prior contact, my concern was that fewer landowners would be willing to talk to me, a complete stranger, if they knew I wanted to record them. According to Babbie (2010), interviewees are less trusting of interviewers that they are not interacting with face to face. This idea was supported by the refusal of several people to speak with me, as well as the stated concern of one interviewee about being recorded.

While I did not expect to capture every word spoken by the interviewees through note taking, I still wanted to ensure that this method was capturing the main points made by the interviewee. In order to analyze how well note taking worked to capture interview information, I conducted two mock interviews with family and friends who are not forest owners, but answered the interview questions as though they were. These interviews were recorded and I took detailed notes during them. I then listened to the recordings and compared the number of words spoken by the interviewees in the recordings to the number of words I had written. The result of this was that I captured approximately $77.3 \%$ of the total words spoken in the interview. When words such as "well", "and", "the", and "oh" were removed from analysis because of their unimportance to the answers, I captured approximately $82.6 \%$ of the words spoken. While this exercise proved useful in reassuring that 
taking detailed notes was capturing the majority of the information, many of the words that were missed were superfluous. In listening to one recording a second time, I found that many of the words missed in the notes were repeated phrases or information that was not relevant to the research. Another issue with this method of testing the effectiveness of note taking is that individual words are not of great interest in this research, unlike in some ethnographic or cultural research, such as linguistics studies or oral histories. The interviews were also conducted in my native language, so recording the specific wording of answers was also not a high priority. This test provided some validation that taking detailed notes captures the majority of the pertinent information, though there were some biases with this method.

\section{Data Analysis}

In order to analyze my interview data, I began by coding my data. I developed a preliminary list of codes based on the questions I asked in the interviews and the information in which I was initially interested. While reading through the data, I looked for words or statements that dealt with any of my preliminary codes. This process served to index the data and make it easier to find wherever a certain topic was mentioned (Babbie 2010). I also used codes to measure the data; different passages with the same code can be further coded with subcategories to indicate different levels or types of the same idea (Bernard 2006). For example, the code for management (MGMT) could be further divided into MGMT-TMBR or MGMT-WDLF for timber or wildlife management. After I finished coding with the predetermined code list based on what I expected to find in the research, I also coded for themes. Coding for themes does not involve creating codes before reading through the data; codes arise from themes in the data that the researcher was not specifically looking for (DeWalt and DeWalt 2002). This involves looking for ideas brought up by interviewees that are repeated throughout the data. According to DeWalt and DeWalt (2002), this serves to create new hypotheses and to better understand the subject matter. I used both methods of 
coding so I could conduct qualitative and quantitative analyses. The current body of NIPF literature consists mainly of quantitative research. Only a few papers have been published using qualitative methods (Bliss \& Martin 1989, Rickenbach et al 2005, Hujala et al 2007). I conducted both quantitative and qualitative analysis to make these results comparable to the preeminent form of analysis in the field of research, but also to help fill gaps in our knowledge of nonindustrial private forest owner behaviors that might only be gained through a qualitative approach. Either method by itself would not have fully characterized the data.

Once I coded the interview data, I used statistical analysis to answer the research questions of whether NIPF owners' management is influenced by their neighbors and if so, if that influence is direct or indirect. Using the codes that I created for different characteristics of landowners, I grouped similar landowners together. For example, because I am interested in the difference between absentee and resident landowners management, I took every interview that had the code NONRES and put them in a group together. I took the rest of the interviews, which all had the code RES, and grouped them together. I then looked at the other variable I was interested in (management) and calculated the proportion of resident landowners (RES) that had the code MGMT. I was then able to compare this to the proportion of non-resident landowners with this code.

I then performed statistical tests to determine if the difference between the management of the two groups was statistically significant. I used two tests, Pearson's chi-square test and regression analysis, in order to analyze both types of data that I collected. The Pearson's chi-square test can be used to determine whether there is a statistical difference in the proportions of different groups in categorical data. I used a p-value of 0.05 as the threshold of significance.

In order to analyze data that was not arranged into categories, such as land tenure or distance from NIPF land, I used regression analysis. However, regression analysis cannot analyze proportional data. Therefore, I converted all categorical data (for example, RES or NONRES) into numbers. 


\section{Chapter 4: Results}

\section{Sample Characteristics}

My preliminary round of interviewing resulted in 12 interviews. In the second round, I interviewed twenty-two landowners. With all of the interviews included, I interviewed multiple landowners from all but one county (Iron) in the western Upper Peninsula. I was only able to interview one landowner in Iron County. My snowballing sampling method resulted in multiple interviewees from the same communities (Table 4.1, Figure 4.1). My original goal was to conduct between thirty and sixty interviews (preferably closer to sixty) because I planned to use only statistical analysis so a larger sample size would be necessary. However, after altering my questions to be more openended, I instead aimed to conduct around twenty interviews, following the precedent set by previous NIPF research with qualitative analysis (Bliss \& Martin 1989, Rickenbach et al 2004, Salmon et al 2006). More than twenty NIPF owners that I contacted refused to participate in the interview; four people agreed to the interview but did not answer their phones or respond to the e-mail when I contacted them to participate. There were also six people whose telephone numbers were disconnected. At least thirty-five people that I attempted to contact simply did not answer any time that I tried to call them to ask for an interview.

Table 4.1

Interviewees per community by county in the Western Upper Peninsula, Michigan.

\begin{tabular}{|c|c|c|c|c|c|}
\hline County & \multicolumn{4}{|c|}{ Communities } & \\
\hline Baraga & 2 & 12 & 6 & 22 & \\
\hline Dickinson & 18,32 & 33 & & & \\
\hline Gogebic & 9 & 11,13 & & & \\
\hline Houghton & $7,16,17,21,34$ & 3,27 & 24,29 & \begin{tabular}{l|l}
31 & 8,17 \\
\end{tabular} & 19 \\
\hline Iron & 26 & & & & \\
\hline Keweenaw & 5,20 & $4,25,28$ & 23 & 7 & \\
\hline Marquette & 10,30 & 15 & 8,22 & & \\
\hline Ontonagon & 14,34 & 1 & & & \\
\hline
\end{tabular}




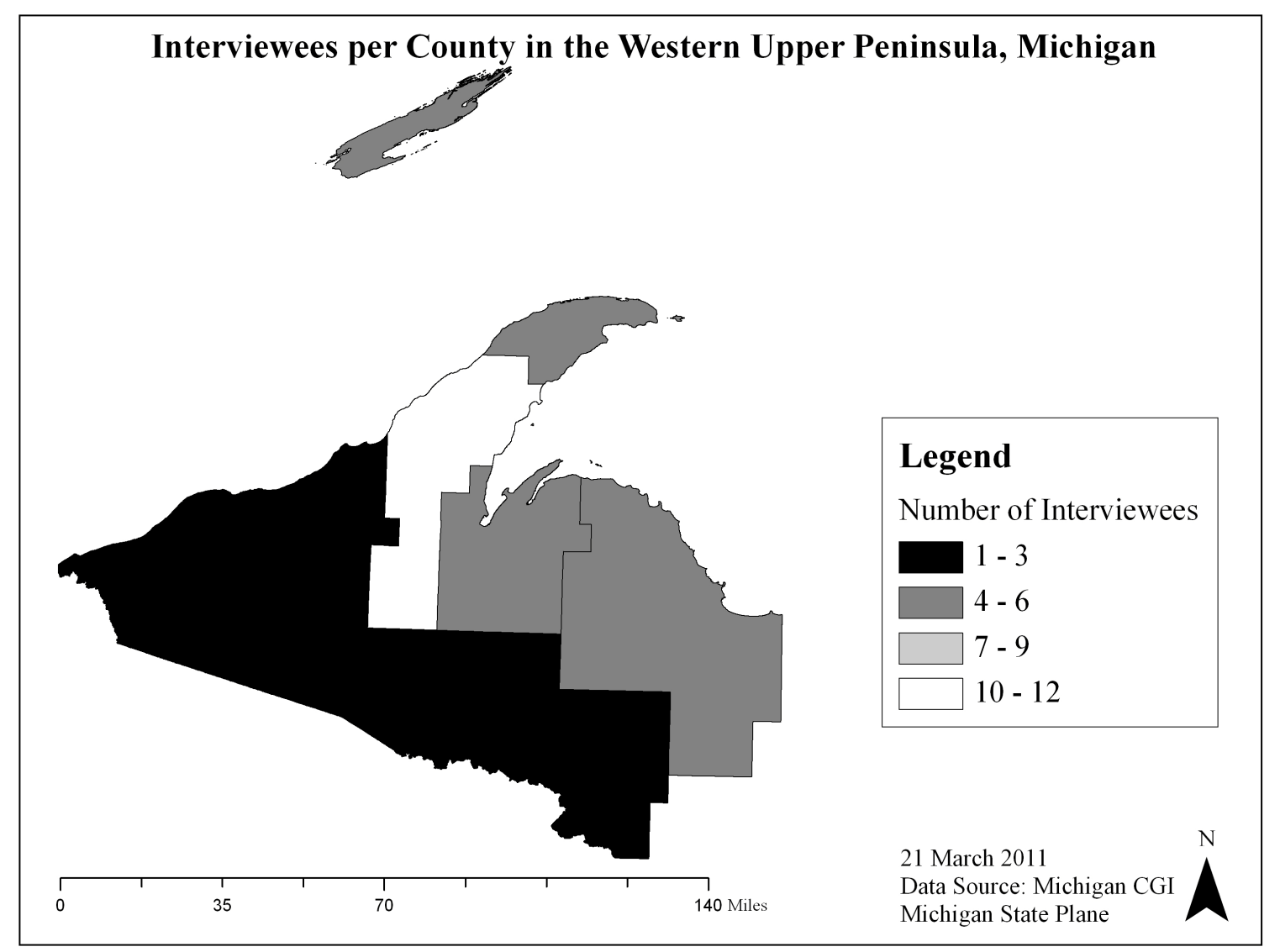

Figure 4.1. Number of Interviewees per County in the Western Upper Peninsula, Michigan.

\section{Landowner and NIPF Characteristics}

I compared demographic information and characteristics of the interviewees' NIPF properties. I first did a simple comparison of the average age, education, land tenure, acreage, and distance of residence from NIPF land, as well as the percentage of landowners who were residents, non-residents, purchasers and inheritors for both samples (Table 4.2). 
Table 4.2

Landowner and NIPF Property Characteristics for Preliminary and Main Samples.

\begin{tabular}{|c|l|r|r|r|r|r|}
\hline \multirow{5}{*}{ Average } & Preliminary Sample & Main Sample & Combined Sample & Standard Deviation & Range \\
\cline { 2 - 8 } & Age & 57.80 & 56.23 & 56.72 & 10.41 & 49 \\
\cline { 2 - 8 } & Years Post-High & & & & & \\
& School Education & 4.27 & 3.59 & 3.82 & 2.96 & 10 \\
\cline { 2 - 8 } & Land Tenure & 22.50 & 21.25 & 21.69 & 17.07 & 79 \\
\cline { 2 - 8 } & Acreage & 242.00 & 247.48 & 245.48 & 440.09 & 2283 \\
\cline { 2 - 7 } & Distance & 74.91 & 99.55 & 91.33 & 175.15 & 600 \\
\hline \multirow{5}{*}{ Percent } & Purchasers & 83.33 & 95.45 & 91.18 & & \\
\cline { 2 - 8 } & Inheritors & 16.67 & 18.18 & 17.65 & \\
\cline { 2 - 7 } & Residents & 50.00 & 40.91 & 44.12 & & \\
\cline { 2 - 7 } & Non-Residents & 20.59 & 50.00 & 70.59 & & \\
\hline
\end{tabular}

I conducted t-tests to determine if the average characteristics for the preliminary sample were significantly different from the main sample (Table 4.3). In order to test the characteristics that are categorical, I converted the categories to numbers. For example, purchasers were " 2 " and inheritors were "1".

There were no significant differences found among landowners in the preliminary and main samples. For all subsequent analyses, I analyzed the two samples as one because the open and close-ended questions were so similar and any differences in landowner characteristics were negligible.

Table 4.3

T-test Results Comparing Preliminary and Main Sample Characteristics.

\begin{tabular}{|l|r|}
\hline Age & P-Value \\
\hline Years Post-High School Education & 0.70 \\
\hline Land Tenure & 0.54 \\
\hline Acreage & 0.84 \\
\hline Distance & 0.97 \\
\hline Purchasers vs. Inheritors & 0.71 \\
\hline Residents vs. Non-Residents & 0.92 \\
\hline
\end{tabular}




\section{Owner Characteristics \& Forest Management}

I asked several questions related to the way that NIPF owners managed their land. I also asked questions about whether my interviewees manage similarly to their neighbors and if not, what is different. The information I obtained about forest management included: whether interviewees were actively managing, if written management plans were used, whether interviewees participate in any landowner incentive programs and why, and if they are receiving advice about how to manage their land.

I used both chi-square tests and regression analysis to analyze the data. I used both tests because some of the interview questions resulted in categorical data and some in continuous data. Continuous data works better in regression analysis, but I also converted some of this data into categorical data so I could compare the results of the two tests to see if a different type of analysis would give a significantly different result. For the purposes of this analysis, interviewees that owned their land for 10 years or more were categorized as long-term owners. The categories for education were college or no college. Some interviewees owned multiple NIPF properties and thus were residents and non-residents; everyone in this situation was classified as a resident. There were also landowners that inherited one NIPF property but bought another. These interviewees were classified as inheritors. For the tests analyzing management differences between education levels, thirty-three interviews were used instead of the full thirty-four because one interviewee did not want to specify their education level.

Categorical test of owner characteristics and management

Table 4.4

P-Values from Pearson's Chi-Square Tests for Demographic Characteristics and Management Activities.

\begin{tabular}{|l|r|r|r|r|} 
& Tenure & Resident/Non-Resident & Education & Inheritor/Purchaser \\
\hline Management & 0.728 & 0.108 & 0.138 & 0.282 \\
\hline Management Plan & 0.728 & 0.522 & 0.209 & 0.955 \\
\hline Program Enrollment & 0.448 & 0.982 & 0.333 & 0.495 \\
\hline Management Advice & 0.002 & 0.105 & 0.618 & 0.452 \\
\hline
\end{tabular}


Using a confidence interval of $95 \%$, the only result that is statistically significant is management advice and tenure. Long-term owners were more likely to have a management plan than short-term owners. Several other factors were close to being statistically significant because their p-values are below 0.2 ; the lack of significance may be a function of sample size.

I conducted the same analyses a second time, and reclassified three interviewees as inheritors instead of purchasers, and five interviewees as non-residents instead of residents. This set of eight interviewees had more complicated ownership histories that made categorization difficult. These interviewees owned at least two properties and bought at least one, and inherited another, or lived on one, but did not consider the other to be a residence. I conducted the test a second time with data from these eight interviewees reclassified in order to see if this would alter the results significantly. The results are as follows.

Changing the interviewees who were classified as both inheritors and purchasers to purchasers had a greater effect on statistical significance than altering the classification of resident and non-resident landowners (Table 4.5). The differences in the proportions of active managers and program participants between inheritors and purchasers were highly significant; this is because no inheritors refrained from active management. The result of the test for differences in management plans was not statistically significant, but it was much closer to being significant than the original test. Inheritors and purchasers were no different in whether they received management advice. The difference in results for the tests using residents and non-residents were less pronounced, but still different from the original test. The difference in residents and non-residents' with regards to whether they actively manage, have a management plan, and receive management advice was more pronounced than in the first test, while the difference in their program enrollment was less pronounced. 
Table 4.5

P-Values from Second Run of Pearson's Chi-Square Tests.

\begin{tabular}{|l|r|r|}
\hline & Resident/Non-Resident & Inheritor/Purchaser \\
\hline Management & 0.549 & 0.000 \\
\hline Program Enrollment & 0.549 & 0.185 \\
\hline Management Advice & 0.768 & 0.000 \\
\hline
\end{tabular}

Regression test of owner characteristics and management

In order to recapture some of the detail lost from converting continuous data to discrete for the chi-square tests, I used regression analysis to analyze all of the data that could be construed as continuous. I assigned numbers to management and no management. The interviewees either actively managed their land (1) or did not manage (0). Instead of analyzing management behavior based on differences in residence, I used the distance that the NIPF owners lived from their forest property. However, in using distance, I had to eliminate one interviewee from this analysis because they put the distance in terms of time to travel to the NIPF from their residence and I was not able to find the actual distance. I was also able to incorporate age and acreage into this analysis. I determined the number of years of post-high school education by using the typical length for the degree that the landowner achieved. In a few instances, landowners gave less specific information about education; for those that said some college, I used two years. For the first run of the regression analysis, I used the distances given to me by the landowners; if a landowner lived on their NIPF land, but owned another property as well, I used zero as the distance from NIPF property. This is essentially the same way that I classified landowners that were both residents and non-residents for the first chi-square tests. 
Table 4.6

P-Values from Regression Analysis of Demographic Characteristics and Management Activities.

\begin{tabular}{|l|r|r|r|r|r|} 
& Tenure (years) & Distance from NIPF (mi) & Education (years) & Age (years) & Size (ac) \\
\hline Management & 0.339 & 0.125 & 0.218 & 0.571 & 0.624 \\
\hline Management Plan & 0.931 & 0.964 & 0.170 & 0.863 & 0.023 \\
\hline Program Enrollment & 0.829 & 0.302 & 0.277 & 0.984 & 0.099 \\
\hline Management Advice & 0.493 & 0.844 & 0.548 & 0.310 & 0.281 \\
\hline
\end{tabular}

The results from the regression analysis were consistent with those obtained from the Chi square analysis (Table 4.6). Land tenure was the only variable that resulted in significantly different management practices (Table 4.3), but no differences were detected when regression analysis was used. The only difference that became more pronounced with regression analysis was that of active management across land tenure lengths. When the number of years of education was used rather than the categories of college or no college, the differences in every kind of management, except whether the NIPF owners actively managed were more pronounced.

The first category that was not tested using chi-square was distance from NIPF (to residence). The difference in whether NIPF owners actively manage based on how far away they live was found to be substantial. The age of landowners was not very likely to have any effect on their management behaviors. The size of the NIPF property had a significant impact on whether or not NIPF owners had a management plan for the property. This could be due, however, to the fact that one landowner with 2,290 acres had a management plan. This may also be true for program enrollment.

While it appeared that distance from NIPF land to residence had no impact on the management behaviors of NIPF owners, I ran a second test using different values for landowners who were both residents and non-residents of NIPF properties. Instead of assuming they were all residents and giving the distance a value of zero, I filled in the actual value they gave me for the distance of the NIPF property that they live on to their other NIPF property. Reclassification made no difference in the relationships observed (Table 4.7). The influences of distance on active management and the presence of a management plan are more pronounced, but not by much. The opposite is true for program enrollment and management advice; distance seems to have less of an effect on 
these behaviors when using the distance of an NIPF residence from another NIPF property instead of considering the distance to be zero.

Overall, the results from both Pearson's chi-square tests and regression analyses illustrated that NIPF owner characteristics, and those of their properties, have little influence on their management activities. The only statistically significant differences were between inheritors and purchasers of NIPF land, long and short-term owners, and different NIPF property sizes (Table 4.8). However, there were several other factors that may have been statistically significant had the sample size been larger.

Table 4.7

P-Values from Second Run of Regression

Analysis.

\begin{tabular}{|l|r|} 
& Distance from NIPF (mi) \\
\hline Management & 0.103 \\
\hline Management Plan & 0.877 \\
\hline Program Enrollment & 0.328 \\
\hline Management Advice & 0.854 \\
\hline
\end{tabular}

Table 4.8

Statistically significant results from Chi-square and Regression Analyses.

\begin{tabular}{|l|l|l|l|}
\hline \multicolumn{1}{|c|}{ Tenure } & Size (ac) & Inheritor/Purchaser \\
\hline Management & & & \\
\hline Management Plan & & 0.023 & \\
\hline Program Enrollment & & & \\
\hline Management Advice & 0.02 & & \\
\hline
\end{tabular}




\section{Neighbor Interaction and Management}

Some of the information about neighbors that I gathered could not be analyzed quantitatively using statistics. For example, the question "have you ever done or avoided doing something on your land because of the way it worked or failed on your neighbors' land?" was meant to determine whether interviewees were influenced directly or indirectly (if at all) by their neighbors. However, the answers to this question were difficult to quantify. I chose not to include that question in the analysis.

The question "How many neighboring landowners do you know?" was not immediately useable because of the wide variety of responses I received. Many people took the question to mean "how many adjacent neighbors do you know". Some assumed I only cared about those they were friends with and some thought it was everyone whose name they knew. The answers to this question varied; I had responses such as "some" or "most" or "five" or "all adjacent". I gave each response a value; if the interviewee knew all of their neighbors, the response was categorized as a two. If they said they knew some or a few, it was a one, and if they knew none, it was a zero. This data was also problematic because I did not ask the question in the first half of the preliminary interviews, so the sample size is smaller. However, I still analyzed this data because, though it was difficult to categorize, it was not so subjective that it was impossible.

The other information about neighbors that I analyzed quantitatively included: if interviewees recommended a neighbor, if they communicated about management with their neighbors, if neighboring NIPF management was known, and if it was similar to the interviewee's management. I tested whether these relationships with neighbors are different among demographic groups and different NIPF characteristics.

\section{Categorical test of neighbor influence}

The first tests I conducted were Pearson's chi-square tests for categorical data. For the first run of the Pearson's chi-square tests, I used the same procedure for classifying non-residents vs. residents and inheritors vs. purchasers that I used when generating the results for Table 4.4. 
Table 4.9

P-Values from Pearson's Chi-Square Tests for Landowner and NIPF Characteristics and Neighbor Relationships.

\begin{tabular}{|l|r|r|r|r|}
\hline Communication with Neighbor s & Tenure & Resident/Non-Resident & Education & Inheritor/Purchaser \\
\hline Recommendation & 0.456 & 0.831 & 0.561 & 0.07 \\
\hline Neighbor Management Known & 0.112 & 0.002 & 0.199 & 0.874 \\
\hline Neighbor Management Similar/Different & 0.152 & 0.982 & 0.425 & 0.018 \\
\hline
\end{tabular}

The effects of tenure on relationships with neighbors seem to be the most pronounced; there was a significant difference between short and long-term tenure in whether the interviewees know how their neighbors manage (Table 4.9). I performed the second set of Chi squared analyses on the reclassification of the landowners who were both residents and non-residents and purchasers and inheritors (Table 4.10). However, I could not reevaluate the purchasers/inheritors category along with neighbor management (similar or different) because in order to conduct a chi-square test, there must be two distinct choices in each category. Tests on the neighbor management similar/different category were not possible, as all of the interviewees that knew their neighbors' management were purchasers.

The reclassification of the resident/non-resident category and the purchaser/inheritor categories produced different $\mathrm{p}$-values from the original tests. However, it did not bring any additional values into the significance at the $95 \%$ confidence level. The relationship between the resident/non-resident category and whether interviewees recommended neighbors was actually moved out of statistical significance from this test.

Table 4.10

P-Values from Second Run of Chi-Square Test.

\begin{tabular}{|l|r|r|} 
& Resident/Non-Resident & Inheritor/Purchaser \\
\hline Communication with Neighbor s & 0.715 & 0.227 \\
\hline Necommendation & 0.064 & 0.599 \\
\hline Neighbor Management Known & 0.559 & 0.118 \\
\hline
\end{tabular}




\section{Regression test of neighbor influence}

The next step in analysis was to conduct regression analyses on the continuous data. As with the regression analysis for the forest management data, this involved eliminating some categories, such as resident/non-resident and purchaser/inheritor, and adding others, including: size of property, years of post-high school education, age, length of ownership (tenure in years), and distance of residence from NIPF property. The distance of residences from forest property had to be analyzed twice in order to account for landowners that live on an NIPF property but own another some distance away. I first ran the regression analysis using zero as the distance for this group of landowners, then ran it again using the distance from the NIPF on which they reside to their other NIPF property.

To convert categorical variables into continuous, I recoded values as follows: if an interviewee communicates with their neighbor, they are given a one; if they do not, they are given a zero. I also created different levels for communication; if the interviewee communicated about management they were a two. If they communicated about something else NIPF related, they were a one, and if they did not communicate at all about their land, they were a zero. A similar procedure was used for the amount of neighbors known by the interviewee.

Table 4.11

P-Values from Regression Analysis of Landowner and NIPF Characteristics and Relationships with Neighbors.

\begin{tabular}{|l|r|r|r|r|r|}
\hline & Tenure (years) & Distance from NIPF (mi) & Education (years) & Age (years) & Size (ac) \\
\hline Communication with Neighbors & 0.389 & 0.292 & 0.715 & 0.327 & 0.697 \\
\hline Level of Communication & 0.353 & 0.168 & 0.964 & 0.577 & 0.880 \\
\hline Neighbors Known & 0.995 & 0.396 & 0.937 & 0.240 & 0.757 \\
\hline Recommendation & 0.284 & 0.165 & 0.205 & 0.607 & 0.151 \\
\hline Neighbor Management Known & 0.209 & 0.186 & 0.951 & 0.903 & 0.805 \\
\hline Neighbor Management Similar/Different & 0.375 & 0.194 & 0.824 & 0.096 & 0.173 \\
\hline
\end{tabular}


None of the results from the regression analyses were statistically significant (Table 4.11). The distance from residence to NIPF property seemed to be a potentially significant factor in the number of neighbors known, whether neighbor management was known and if it was similar, and the level of communication with neighboring NIPF owners. No other factor seemed to show as great of a difference as the distance from NIPF to residence. I ran a second set of regression analyses in order to see if a different classification scheme for the distance from NIPF to residence would change the significance of relationships (Table 4.12).

The results of the second set of regression analyses with an altered classification scheme for the distance from NIPF to the interviewees' residences were again not exceedingly different from the first run of tests. Overall, there were very few statistically significant results from the tests of neighbor relationships (Table 4.13).

Table 4.12

P-Values for Second Run of Regression Analysis.

\begin{tabular}{|l|r|}
\hline Communication with Neighbor s & Distance from NIPF (mi) \\
\hline Level of Communication & 0.299 \\
\hline Neighbor s Known & 0.162 \\
\hline Recommendation & 0.443 \\
\hline Neighbor Management Known & 0.204 \\
\hline Neighbor Management Similar/Different & 0.149 \\
\hline
\end{tabular}

Table 4.13

Statistically Significant Results from Chi-square Analysis.

\begin{tabular}{|l|r|r|r|}
\hline & Tenure & Resident/Non-Resident & Inheritor/Purchaser \\
\hline Recommendation & & 0.002 & \\
\hline Neighbor Management Known & 0 & & 0.018 \\
\hline
\end{tabular}


In summary, the majority of the results from analysis were not statistically significant. This was not unexpected due to the small sample size. However, some significant correlations were discovered (Table 4.14).

Table 4.14

Summary of Significant Results and their Relationships.

\begin{tabular}{|l|l|l|}
\hline Characteristic 1 & Characteristic 2 & Direction of Relationship \\
\hline \multirow{2}{*}{ Tenure } & Management Advice & Negative \\
\cline { 2 - 3 } & Neighbor Management Known & Negative \\
\hline Size & Management Plan & Pos itive \\
\hline Resident & Recommendation & Positive \\
\hline \multirow{3}{*}{ Purchaser } & Neighbor Management Known & Positive \\
\cline { 2 - 3 } & Management & Negative \\
\cline { 2 - 3 } & Program Enrollment & Positive \\
\hline
\end{tabular}




\section{Chapter 5: Discussion}

The quantitative analysis I conducted on the interview data yielded very few significant results. The first questions I analyzed from the interviews were those about management and demographics. This information was not pivotal to my research, but was interesting to me because it has been included in much of the previous NIPF literature (Amacher et al. 2003, Beach et al. 2005, Joshi and Arano 2009). Knowing how the interviewees manage their land is also essential because the purpose of my research is to better understand NIPFs since they are capable of having a huge impact on the forest landscape in the western Upper Peninsula. The only statistically significant result from this analysis was the relationship between land tenure and whether or not the owner received management advice. The landowners that did not receive advice tended to have long land tenures, but they comprised a small portion of the total interviewees. Land tenure was not a significant factor with regards to other types of management. When I conducted regression analysis on land tenure's effect on management, the number of years rather than long or short-term ownership was used. This yielded no significant results. This is contrary to the results of previous research which found that tenure was positively correlated with the likelihood of harvest (Joshi and Arano 2009, Voukon et al. 2010). Other research showed that there was a significant positive relationship between length of ownership and participation in or application to programs (Stevens et al. 2002, Matta et al. 2007, Sun et al. 2009).

Whether the interviewees were residents of their property or not had no significant impacts on their management activities. However, the tests for residency's impact on the likelihood of receiving management advice yielded results that were close to significance; with a larger sample, residency may have decreased the likelihood of receiving management advice. While my research did not find significant differences between resident NIPF owners and non-residents, this was not the case in other research. One study found that being a resident landowner increased the probability of harvesting at 50\% intensity (Voukon et al. 2010). Previous research has also found that residency had a positive correlation with program participation for a variety of different programs (Nagubadi et al. 1996, Stevens et al. 2002, Matta et al. 2007, Jarrett et al. 2009). 
The level of education of NIPF owners also had no significant impact on management activities. Landowners were classified as college or no college for the chisquare tests. For regression analysis, years of post-high school education were used instead. Both tests, however, had results that were close to significance for the variables of active management and the presence of a written management plan. A 2002 study found that education level was significantly positively correlated with having a written management plan, so again, the fact that I did not find this may have been a function of the small sample size rather than the absence of a significant relationship (Bovee and Holly 2002). Many previous studies have also found education level to be positively correlated with active management (Beach et al 2005, Stordal et al. 2008, Joshi \& Arano 2009). Previous NIPF literature showed positive relationships between education level and program participation, while my research showed none.

The difference between inheritors and purchasers of NIPF properties has been shown in some studies (Joshi and Arano 2009, Voukon et al. 2010) to have an effect on management activities. In the first run of the chi-square tests, landowners who inherited one NIPF property and purchased another were classified as inheritors. This test yielded no significant results. When I reclassified landowners that had both inherited and purchased NIPF properties as purchasers, I found that active management and program enrollment were significantly different between purchasers and inheritors. Landowners that inherited NIPFs were more likely to actively manage than those who purchased their properties (even if they also inherited a property). Purchasers, on the other hand, were more likely to participate in programs than inheritors. The difference between purchasers and inheritors with regards to having a management plan was much closer to significance than in the first run of the test; inheritors were more likely to have a management plan than purchasers. The reason for this difference in results when owners that are both purchasers and inheritors are considered as purchasers could be due to the lack of owners that have only inherited; in these chi-square tests, there are only three landowners that are classified as inheritors.

Regression analysis on the distance of NIPF from primary residence yielded no significant results with regards to management behavior, though the effect of distance on 
active management appeared to be close to significance. Landowners that lived far from their properties seemed to be less likely to actively manage than those that lived closer or on their NIPF property. Management behaviors were also not significantly different between landowners of different ages. This was contrary to what I expected because many previous studies have found significant differences between age groups. Several found age to be negatively correlated with probability of timber harvest (Romm et al. 1987, Beach et al. 2005, Joshi \& Arano 2009). Others found age to be positively correlated with program participation (Finley et al. 2006, Sun et al. 2009).

The final variable I examined with regards to management activities was size of NIPF. This factor was important to examine because it has been included in so many other studies and there was such a wide range in my data. There was a statistically significant difference between properties of different sizes with regards to having a management plan. Larger properties were more likely to have a written management plan in place. The reason for this trend could be that smaller NIPF properties do not need a management plan as they may be too small to do much active management. Another possible reason is that program enrollment may be more worthwhile on larger properties because of the tax benefits, and most of the programs with such benefits require written management plans. Some extremely large properties had management plans which may have biased the results of the analysis. The result for the test of program enrollment with size was very close to significance with a p-value of 0.099 . This, again, could have been biased by one very large property's enrollment in programs. One study found that program enrollment was positively correlated with the size of the NIPF property (Finley et al. 2006). The fact that only one variable was significant in my data was a surprise because the size of NIPF properties has been examined many times before and has been found to be significant in many studies, particularly with regards to harvesting behavior.

The next tests that I conducted were on landowner relationships with their neighbors. I looked at differences in communication, recommendations, if they knew how their neighbors managed, and how their management compared to their neighbors. The distance and land tenure were especially important to test because it is logical to think that the further the owner lives from the NIPF property and the less time they have 
owned it, the less influence their neighbors will have on them. Land tenure was significantly different with regards to whether landowners knew how their neighbors managed. The average land tenure of owners that did not know how their neighbors managed was higher than that of owners that knew about their neighbors' management. This result was unexpected; I hypothesized that landowners who owned their land for a long time would be more likely to know about their neighbors' management. One possible explanation for this result may be that landowners with long land tenure are more likely to be elderly, and may not be as mobile or as social as short tenure, younger landowners. The results for similar vs. different neighbor management and whether or not the owner provided a recommendation were both very close to being significant, while differences in neighbor communication were not. Longer tenure owners were more likely to recommend neighbors, which was what I expected. Landowners with longer tenures were less likely to have similar management to their neighbors, which was also a surprising result. Again, a possible explanation for this may be that long term landowners are most likely to be elderly and have restricted mobility, so they may not know how their neighbors manage. Another reason could be that long tenure landowners have been managing in a certain way for a long time, and may not want to alter their management even if different practices are more prevalent. Rickenbach and Kittredge (2009) found the length of ownership had a large impact on the number of neighbors known; the possibility that my research would not reflect this was unanticipated.

The difference between residents and non-residents' propensity to recommend neighbors for interviewing was statistically significant. Residents were more likely than non-residents to recommend neighbors for interviewing, which was what I hypothesized would happen. If they live on their NIPF property, they have greater exposure to their neighbors. The difference in residency was also almost statistically significant with regards to how similar their management was to their neighbors'. Surprisingly, nonresidents were more likely to have similar management to their neighbors than residents. This is contrary to my hypothesis; I predicted that NIPF owners would know each other better and conform to each other's management if they lived near each other year round. 
There were no significant results from the tests for education level. The difference in whether interviewees gave a recommendation, between college educated interviewees and those who did not attend college, was close to significance. Interviewees with some college were more likely than those with no college education to recommend neighbors.

The difference between inheritors and purchasers was significant only in whether they knew what their neighbors' management activities were. Landowners that inherited their land were significantly less likely to know how their neighbors manage. This result was surprising to me because I hypothesized that inheritors would know neighboring landowners better and be more aware of what is happening on the land surrounding theirs since that land was presumably in their family for some time. However, all landowners that were inheritors of at least one property were also non-residents of at least one of their NIPF properties; they may not be as aware of their neighbors' activities because they do not live nearby. The result for communication with neighbors was not significant, but was very close to significance. Purchasers of NIPF property were more likely to communicate with their neighbors than inheritors. Another explanation for these results, besides the fact that only one inheritor was not a non-resident, may be that inheritors did not chose to own their NIPF property and may not spend as much time on it and interact with the neighboring landowners as much as someone who purposely obtained an NIPF.

When regression analysis was used to evaluate neighbor relationships, there were no significant results. The difference in distances of primary residence to NIPF property was very close to significant in the level of communication with neighbors, whether neighbors were recommended, the number of neighbors known, and whether neighbors managed similarly or different. NIPF owners that lived far from their property were less likely to recommend neighbors for interviews than those who lived close to or on their properties, which was the expected result. Though the landowners who knew the most neighbors and had the highest level of communication with them lived closest to their NIPF property as expected, NIPF owners with similar management to their neighbors lived significantly further from their properties on average than those with different management. This could, however, be due to two landowners that lived substantially 
further from their NIPF properties than other owners. Most of these results make sense based on my hypotheses, as well as previous studies. Rickenbach and Kittredge (2009) found that distance was the most influential variable on neighbor relationships and that landowners living a shorter distance from their NIPF knew more neighbors. Although I would have expected the tests for differences in distances to be significant, most of the results were what I expected and, given the sample size, the p-values were not entirely unexpected.

Age had no significant impacts on neighbor relationships, though different ages seemed to have close to significantly different neighbor management. The test on the size of NIPF property also yielded no significant results. Neighbors with larger NIPF properties were, on average, more likely to recommend neighbors than those with smaller properties. Owners with different sizes of NIPF properties also had close to significant differences in management with their neighbors. NIPF owners with management different from their neighbors had higher average property sizes. If the neighbors of these large NIPF properties have much smaller properties, I would expect their management to differ because less management may be possible on smaller properties. Another possibility is that people who own larger properties might be more inclined to do a lot of active management because they value owning NIPF land more highly, as evidenced by their ownership of large tracts of land.

All in all, there were far fewer statistically significant results than I had expected based on previous NIPF research and my hypotheses. My two main research questions were:

\#1. Are the management decisions of NIPF land owners in the western Upper Peninsula of Michigan influenced by their neighbors?

\#2. If neighbors are influencing each other's management, is it indirectly or directly?

I did not directly address these questions with quantitative analysis because influence was difficult to quantify; however, I did analyze other data that was related to influence. I hypothesized that the newer kind of landowners (non-rural and short-tenure) would be less likely to be influenced by their neighbors because 
they would not know them as well. The results of the statistical analysis showed that tenure was not a particularly significant determinant of neighbor relationships. When substantial relationships appeared, they were not always what I expected in that owners with short tenures seemed to know more about their neighbors than owners with long tenures. The differences between landowners that live far from their land and those that live close to or on their NIPF land were not significant, which was also unexpected because Rickenbach and Kittredge (2009) found distance to be the most influential variable in the number of neighbors known. While the results were not significant, distance did behave with other variables as I expected. A major factor in the lack of statistical significance was most likely the small sample size, which does not easily lend itself to statistical analysis. The presence of any statistically significant results with such a small sample is encouraging.

\section{Qualitative Analysis}

Although I analyzed many of the interview questions using statistics, it is hard to learn much from using statistics on such a small sample size. There were also a lot of open-ended questions and much of the detail in the answers to these questions is lost in quantitative analysis. Qualitative analysis also produces new ideas and conclusions that may not be seen with quantitative analysis because quantitative analysis focuses on predetermined hypotheses.

The first theme that I examined was the idea of influence. Within this, I created subcategories of direct and indirect influence. I used these themes to examine my research questions of whether landowners are influenced by their neighbors and if so, if they are influenced directly (such as through conversations or referrals to sources of advice) or indirectly (through observing their neighbors' management activities). This was done with qualitative rather than quantitative analysis because the answers were subjective and difficult to classify. There were some landowners that were influenced both directly and indirectly by their neighbors' management. Interviewee \#21 manages for timber, similarly to his neighbors. He talks to his neighbors about their management, but was also indirectly influenced by them. While his management itself would not be 
impacted, he said he would not use the loggers his neighbors did because he did not like what they did on neighboring properties. Interviewee \#22 had the opposite experience with logging companies; his neighbors recommended a logging company to him that he has continued to use. He was also indirectly impacted by his neighbors' management in that he would not cut too much from his land because of the way some of his neighbors cut theirs. Landowner \#6 purchased her property for recreational purposes, so harvesting timber may not have been an activity she would be interested in anyway. However, she did say that she and her husband thought that the loggers on their neighbor's property made a mess. She said they would never log because of that and because her neighbors told them about their bad logging job. Interviewee \#9 managed for deer habitat and collaborated with his neighbors on different methods of deer management. He was also influenced indirectly by his neighbors because his neighbor had a select cut done and interviewee \#9 was not impressed with the results; he said they had rutting and a lot of stumps left.

The most striking example of a landowner influencing others was in my interview with \#19. His property is near the NIPF properties of his father and uncle, so he speaks with them often about his management and uses the same forester. They are both influenced indirectly by other neighbors; he said they demanded a winter harvest because they have seen what can happen on local soils when landowners allow summer harvests. He and his father also directly influenced other neighbors by encouraging one to use the same forester and harvest in winter; this neighbor in turn convinced five or six other neighbors to harvest at the same time in the same way. It is possible that landowners in this community think of interviewee \#19 and his father as opinion leaders. The area around their NIPF property was collaboratively managed because of their influence on neighbors.

Some of the interviewees' answers to questions about influence led me to believe that they were influencing their neighbors directly, though the interviewees did not necessarily see their influence. For example, the first interviewee said that he was not influenced by his neighbors, but in the past, I suspect he directly influenced his neighbors. He and his family logged all of his neighbors' properties for them, so he 
probably had some direct influence on what he did on the land. Interviewee \#11 is a forester and did not take his neighbors advice, but they asked him about his management. This indicated to me that he may be considered an opinion leader in his community because of his knowledge of forest management. He may have influenced their management, but he was not sure if they actually cared what he had to say or if they were just interested in how to make money on their land. Many landowners may not realize that just by speaking to their neighbors about their NIPF management, they may be influencing or influenced by them.

I wanted to see if the amount and type of influence changed with different land tenures and distances from residence in order to better understand the newer type of landowners. Six of the fifteen landowners who were residents of their NIPF lands were seemingly not influenced by and did not influence their neighbors with regards to land management. Thirteen of the twenty-four landowners that were non-residents showed no influence in their interviews; however, five of these landowners communicated with their neighbors. While they may not believe that their neighbors are having any influence or that they are influencing their neighbors, again, they may be taking in information about management without realizing it. My hypothesis that non-resident landowners would be less influenced by their neighbors was therefore neither proven nor disproven; similar proportions of each group appeared to have no influence on or from their neighbors. Six of these landowners living within fifty miles of their land were in the category of no influence, and six of the landowners living further than fifty miles away were in this same category.

With regards to tenure, 12 out of 26 of the landowners that owned their land for ten or more years had no management influence, though two of these communicated with their neighbors. The proportion of long-term owners that were influenced by or influenced their neighbors was higher than that of short-term owners. This supports my hypothesis that landowners who owned their land for longer would be more likely to be influenced by their neighbors. 


\section{Privacy and Policy Impacts}

One theme within the data was privacy. While my original hypotheses centered on landowner relationships with their neighbors, it seems that privacy may be just as important of a factor in what they do on their land, particularly with regards to program enrollment. The code "PRIV" was used whenever landowners brought up acting in a certain way to preserve privacy and property rights. When I asked interviewees if they were enrolled in any kind of program for NIPF land, the majority said no, which is evident in the statistical analysis. However, what is not seen in the statistics is the reason behind their low participation in landowner assistance programs. Five out of the twentytwo landowners in the main sample specifically mentioned that they found a drawback to programs such as Commercial Forest to be the forfeiture of privacy on their NIPF land.

A few landowners mentioned privacy in the interviews when discussing their management or reasons for owning their land as well. When asked if their neighbors' management had ever impacted their view of certain activities, interviewee \#5 said that there are things he would not do on his land because he would not want to impact his neighbors' viewshed. His land had been affected by neighbors' activities, so he is careful not to do anything to compromise their privacy. Interviewee \#7 mentioned privacy with regards to his purchase of NIPF land. In answer to my question about the number of neighbors known, he responded "all of them, unfortunately." Throughout the course of the interview, he made mention several times of the fact that he wanted to be in the country, away from other people. He also said that his property in Baraga County, where he knows all of his neighbors, is not wild enough for him. Interviewee \#3 had a similar desire in owning NIPF land; he said that he purchased his property because "that's the kind of guy I am, I'm not a city dweller." Interviewee \#5 also cited his reason for purchasing as the wish for a "private nature sanctuary". Another interviewee, \#12, also mentioned that one reason she and her husband purchased a property in the Upper Peninsula was for the remoteness and the lack of structures. This was a common theme for many interviewees; they may have purchased their property for a residence, but their reason for specifically choosing an NIPF property was the privacy it offered them. 


\section{Value of Nature}

Another common theme in the interviews was the inherent value of nature. Many interviewees cited naturalness and wildness as reasons for owning their property. They not only wanted their privacy, but as interviewee \#5 said, he wanted a private nature sanctuary. This also affected the management of many interviewees. Interviewee \#4 said that he saw no reason to manage and that the only reason people manage their forest is to make money to pay the property taxes. This brings up another idea I noticed in the research, which I thought to be somewhat opposite the theme of nature's inherent value. This was the utilitarian value. The interviewees who wanted their land to be natural and wild typically did not manage or do anything to alter their land because they liked in the way it was and they did not think human interference was necessary to improve on nature. Those I found with the utilitarian viewpoint, however, made statements about having to log their land because it was necessary for the health of the forest. They were of the opinion that forests need to be managed by people to be productive. Many of these same interviewees managed their forests to work for them; their reason for ownership was often as an investment. Interviewee \#3, who wanted the land to live outside the city in a rural area, logged his land because he said there was a lot of mature maple and he did not want to let it go to waste. While his reason for owning the land was not as an investment, he was still of the opinion that the land was working for him and needed to be managed.

\section{Recreation and Wildlife}

For some NIPF owners, the desire to own an NIPF can stem from wanting to have a place of their own for recreational purposes. Of the 23 interviewees that gave information on why they purchased an NIPF, 13 interviewees (approximately 56.5\%) cited recreation. Recreation meant a variety of different things to the interviewees, but the most common type specifically mentioned was hunting, particularly for white-tailed deer (Odocoileus virginianus). Interviewees that owned their properties primarily for hunting did not always actively manage their NIPFs, but some did have unique relationships with their neighbors due to their hunting activities. For example, 
interviewee \#2 did not actively manage his property for wildlife habitat, as he wanted to keep it natural for wildlife. His two neighbors also use their properties for hunting. He is good friends with both neighbors; while they don't specifically influence each other's management (because they do not actively manage), they hunt on each other's properties and "watch" each other's properties, as none of them are resident landowners. Unlike interviewee \#2, interviewee \#18 did actively manage in order to improve deer habitat. Her neighbors also used their land primarily for deer hunting. When asked if she spoke to her neighbors about management, she said "Well, maybe just a little bit. We don't work together, though, except for the deer. We try to work together on the bucks we shoot". While they do not communicate about management in the way I was expecting, these interviewees work closely with their neighbors on an aspect of NIPF ownership that they consider to be very important. Jacobson et al. (1996) found that though NIPF owners don't usually cooperate with groups or other owners, if they do, it is most often for hunting purposes.

Recreation, and more specifically hunting, was a major factor in the decision to purchase a forested property; in some cases, it was the sole reason for the acquisition. According to Newman et al. (1996), the new type of NIPF owner is more interested in the hunting and recreational prospects on NIPFs than traditional owners. Hunting seems to have a larger impact on management than recreation as a whole; no interviewees specifically cited activities such as building trails for recreation, while several mentioned managing specifically for hunting ( $\# 8,9,18,19$, and 22). Creighton et al. (2002) found that NIPF owners ranked having a place to hike and camp as more important than having a place to hunt and fish. This is not necessarily contradictory to my results as landowners may value these activities more highly, but may not manage for them. However, based on the interviews I conducted, hunting is an important motivation for acquiring an NIPF and a major determinant in how some NIPF owners manage.

\section{Economics}

Another factor impacting management that I did not consider was economics. A major determinant of the way people managed their land was finances. Several 
landowners' main purpose in owning land was as an investment. Many landowners manage in specific ways because they want or need the income from their land. Others let the market determine when and what they will cut from their forest. For example, interviewee \#9 manages primarily for wildlife habitat improvement, but in doing so, occasionally harvests timber on his land. While his main reason for purchasing an NIPF property was hunting, he refrained from cutting certain species because the market was not good for those species at the time. Despite the fact that he was planning on cutting those species to meet his goals, market pressures were a stronger influence on his management. Interviewee \#17 also lets the market determine his management. He removed more valuable trees, but specifically stated that he "will wait until the price goes up because they'll last longer," meaning that these trees will not over mature quickly so he will harvest them only when he can get the best price. He also stated that he uses his NIPF for cutting firewood, but only cuts firewood from trees that would not make good saw logs. Some of the landowners that I interviewed used finances to determine how they managed more often than a management plan; if they had written plans with specific timelines, their management would have been more predictable and less affected by forest product markets. The drive to economically benefit from NIPFs seemed to be more important to many NIPF owners than any other factors.

Economics also have a large impact on program participation. Many interviewees participated in programs specifically for the purpose of saving money. While the drive to benefit financially from a forested property can lead to haphazard management, it can also result in the opposite outcome and give landowners a reason to follow a planned series of actions on their land. Many landowner assistance programs only give technical and financial aid when the property has a certified management plan. Therefore, even though landowners enroll in programs for financial reasons, their forest management is better for it. Interviewee \#19 purchased his NIPF property partially for investment purposes and he enrolled in Commercial Forest for the property tax reduction. When asked if he had a management plan, he said, "Yes, it's simple. You can't apply to put your land in CF without a written plan." Without the financial incentive of Commercial Forest, this interviewee would probably have not obtained a management plan for his 
property. This interviewee also disliked government interference in private property, but the economic incentive was a more important factor in participation. Stevens et al (2002) found that landowners were more willing to participate in programs and give up property rights with higher economic incentives of any kind. Participating in programs for NIPF owners can also allow landowners to manage their land in ways they may have wanted to, but could not afford. For example, interviewee \#5 and his wife participate in Michigan's Commercial Forest program, WHIP, and LIP. They enrolled because the goals of the programs align with their goals and the cost-share aspects of WHIP and LIP allow them to conduct management that they could not afford without the programs. It is obvious that financial factors have a large impact on management one way or the other.

\section{Governance and Program Participation}

Another theme that presented itself in the interview data was mistrust of government. This was not an entirely surprising result, as it has been mentioned in previous research. Jones and Finley (1993) found that fewer NIPF owners than members of the general public thought of government cost-share programs as effective. Another study found that landowners would not even allow their land to be surveyed for the presence of an endangered species because of their distrust in government (Brook et al. 2003). Shandas (2007) found that NIPF landowners' most trusted sources of information were typically not government; only $5 \%$ of those surveyed trusted county government officials the most, and even fewer trusted information from state and federal sources above others. In my research, landowners who were opposed to government involvement on their NIPF property were typically talking about the Michigan Department of Natural Resources (DNR), as opposed to federal or county level officials. In fact, more than one landowner specifically mentioned receiving assistance from an NRCS employee, and one landowner also stated how helpful having a forester for each conservation district was in the past.

Some landowners were reluctant to have management plans or participate in government-run assistance programs because they do not want government involvement in their land management. Interviewee \#11 said "I don't want the government involved 
in telling me what to do. It places restrictions on it." He also said that he does not talk to state or federal foresters because they do not emphasize his interests, which is basically profit maximization. Another interviewee, \#19, had very strong opinions about government involvement in private forestland, referring them as the Nazi police. He spent a long time during the interview telling me about an incident that led him and other landowners to dislike the DNR. With regards to getting landowners to listen to and trust the DNR, he said "The first thing to do is to get the DNR to portray an attitude of how can we help you, not how can we fine you." Ironically, though he showed the most distrust of government agencies, this did not actually stop him from enrolling in Commercial Forest. While distrust of the government was not widespread throughout the interviews, in those where it was present, the interviewees specifically brought it up without prompting. Even in the close-ended preliminary interviews, \#32 responded to the question about where he got his advice by saying "not the DNR". Four of the interviewees made a point to mention their dislike of government interference.

\section{Gender}

Finally, there was one theme that I noticed before I had even concluded the interviews. When I called potential interviewees, I most often spoke first to wives. However, I began keeping track during the main sample of my interviewing and only four of the interviewees were female. While these women took part in the interviews, more than one of them stated during the interview that her husband would know (about certain questions) or her husband takes care of it. At least six of the women who answered the phone when I called to ask to participate in the interview gave the phone to their husbands because they "knew more about it". I found this to be a very interesting phenomenon. This told me that, with regards to management information, female landowners are not getting sufficient information, from neighbors or otherwise.

\section{Qualitative vs. Quantitative Analysis}

In some cases, the quantitative analysis seemed to yield results contrary to what the qualitative analysis found. For example, the tests for relationships with neighbors 
yielded very few significant results, while I found NIPF owners to be influenced by their neighbors in the qualitative analysis. The statistical tests did not tell me that people were not influenced by their neighbors (only that I may not have had a large enough sample size to detect a relationship), while this influence was clear from the qualitative analysis. The qualitative and quantitative analyses tested different aspects of NIPF ownership and neighbor relationships. The only results that seemed to be directly opposed to each other were the findings that differences in tenure and distance from primary residence to NIPF were not statistically significant, while I found there to be a difference between these groups using qualitative analysis.

Both methods of analysis proved useful in my research. Quantitative analysis allowed me to include the type of information that comprises much of the existing NIPF literature. It also gave definitive answers about the differences between different groups of landowners and the impact of those characteristics on management behaviors. The results from the qualitative analysis were not as clearly defined, but were insightful. Qualitative analysis allowed me to discover important ideas from the data that I had not considered when creating the predetermined interview questions. It allowed for elaboration on some of the almost-significant results from statistical tests; qualitative analysis bolstered the evidence that landowners were influenced by their neighbors.

\section{Future Research}

While I used both forms of data analysis in this study, in the future, I believe that qualitative analysis should be used more commonly in NIPF research. The information I obtained from qualitative analysis was much richer and more descriptive of my sample than the data from the statistical tests. More studies using in-depth interviews are needed to fully understand where and why NIPF owners are getting information about management. Several ideas, such as economics, recreation, and government mistrust, emerged from my interviews in the process of qualitative analysis. Conducting case studies and allowing each interviewee to provide tangential information would likely give the researcher a better idea of what factors are the most influential in NIPF owner decision making and why. Although there were several other factors that influenced how 
people managed as much or more than their relationships with neighboring NIPF owners, from the limited interaction I had with my interviewees, their motivations for land ownership were not always immediately apparent.

\section{Biases}

There are many factors that influenced my research, some beyond my control. These biases could impact the integrity of my data and conclusions. One such bias is in phone interviewing. According to Babbie (2010), telephone interviewing can bias the sample because not everyone owns a telephone, although he did state that by 2003, over 95\% of homes had telephones in the U.S. However, from 1998 to 2005, the number of young adults (under 30 ) that owned landline phones decreased from $93 \%$ to $71 \%$, while their cell phone use increased (U.S. Census 2009). Homeowners aged 65 and older, on the other hand, saw an increase in landlines; 98\% of this demographic had landlines in 2005 (U.S. Census 2009). By the end of 2009, approximately one-quarter of adults had only cell phones and no landlines (Blumberg and Luke 2010). Because my method of choosing interviewees used plat books to find owners, and the phonebook and the White Pages website for their phone numbers, the lack of landline phones probably impacted my sample. There were a lot of landowners that I could not call because I could not find their phone number, either due to their lack of a landline or their number being unlisted. The average age of the interviewees in my sample was 56.72 and there were only two interviewees under the age of forty, and none under age thirty. This could be a simple case of there being more NIPF owners in an older age group in the western Upper Peninsula, but it could also be due to the fact that younger owners simply do not have landlines. Several studies have shown age to be a good determinant of how NIPF owners will manage (Loyland et al 1995, Kuuluvainen et al 1996, Joshi and Arano 2009); if certain groups of owners are not represented, the true spectrum of management activities will not be shown either.

Another issue with using phone interviewing was with non-resident landowners. When I found landowners in the plat book, I searched in the phone book or online White Pages for their contact information. If the landowner did not live in the same area as their 
NIPF land, and they were not enrolled in Commercial Forest (which publishes the addresses of all enrolled owners) it was difficult to find their phone numbers. It is possible to search state or nationwide with a person's first and last names, but this often turns up multiple entries. If that does occur, it is impossible to tell which person of that name is the actual landowner. Therefore, many of the owners that lived outside of the Upper Peninsula or out of state were not included. This could bias the results because according to Jones (1995) the newer class of NIPF owners tends to live further away from their NIPF property, and thus eliminating them from the sample will not properly represent their activities.

The final problem I encountered with phone interviews was the issue of disconnected numbers. Several of the phone numbers that I found were disconnected, either temporarily or permanently. The fact that some were only temporarily disconnected leads me to believe that perhaps these landowners may have another residence. While this is merely speculation, it does not seem unreasonable, given that I was attempting to contact people in the Upper Peninsula out-of-season, and their forested properties may not be where they spend their winters. This could also bias the results because these landowners will not be included.

\section{Conclusions}

The two main questions I attempted to answer with this research were: \#1. Are the management decisions of NIPF land owners in the western Upper Peninsula influenced by their neighbors, and \#2. If neighbors are influencing each other's management, is it indirectly or directly?

The answers to these questions remain elusive because the amount of influence neighbors actually had on the landowners was difficult to quantify. However, by carefully examining the interview data, I found that $50 \%$ of the interviewees' management influenced or was influenced by neighbors; $32.4 \%$ were directly influenced by their neighbors (or directly influenced their neighbors), while 38.2\% were indirectly influenced, or indirectly influenced others. The management of 
approximately $20.6 \%$ interviewees was influenced both indirectly and directly by neighboring landowners. Many of the interviewees discussed management with their neighbors, but claimed that the way their neighbors managed had no impact on their management. Most of these interviewees were considered not to be or have influence. I found that approximately $70.6 \%$ of landowners who claimed they were not influenced by their neighbors also did not manage their NIPF. It would be difficult to influence the management of those interviewees that did not actively manage their land, though some of them could have been influenced against management by their impressions of their neighbors' activities. There were also several factors impacting management that I did not consider. NIPF management was affected by financial pressures, feelings about the government and nature, and desire for privacy. These influences seemed to have just as much, if not more, of an impact on management than neighbors.

\section{Implications of Research}

While there were factors I did not focus on that also had a large impact on NIPF management, this research could influence policy in the future. One trend that I noticed was the preferred advice source. Landowners typically chose local foresters over other sources of advice; this was true especially if they had neighbors that were foresters. It was clear from the interviewees who were foresters that they were their communities' opinion leaders. Information distribution and promotion of landowner assistance programs could be aided by targeting these landowners. Another factor that affects how landowners receive information is the mistrust of government. Although this was not widespread throughout the interviews, there was such a strong sense of mistrust in the interviews where it was mentioned that it seemed noteworthy. The reasons for not wanting government involvement are varied, from property rights concerns to bad experiences with the DNR. Whatever the reason, the image of the DNR is suffering with private landowners. However, some landowners still participated in government sanctioned assistance programs despite their animosity towards government involvement. In order to encourage better management and participation in programs, government 
agencies must improve their image with private forest owners. Emphasizing what the DNR does for landowners may be important in improving their image and increasing program participation. As I previously stated, recreation and hunting in particular are very important to NIPF owners. The DNR controls hunting in Michigan and attempts to regulate deer populations for hunting, making their work essential to those NIPF owners that value hunting. The programs run by the DNR also promote biodiversity and increased deer populations by requiring enrolled land to remain forested. Without these programs, more forests could potentially be converted to other uses, leading to fragmentation and subsequently lower game populations and species diversity. The DNR could encourage landowners to participate in their programs not only for economic reasons, but also to protect their hunting prospects.

Finally, there are several areas where information about management is not present. The first of these is female landowners. Almost every landowner that I spoke to owned their NIPF jointly with their spouse, but only a few women actually participated in the interview. Of those that did participate, most told me that their husband would know better or that he took care of the forest management (or something similar). Women in the western Upper Peninsula represent a demographic that is not reached by management information. Although the reason women were less involved in the management of NIPF properties is not known, educating female landowners on management practices and programs available may help increase program participation and better management. Some research has found women to be more environmentally concerned (Mohai 1992, Stern et al. 1993); if this is true and more information about NIPF management reached female landowners, it is logical to assume that NIPFs actively managed for environmental goals would increase in the western Upper Peninsula. However, as Stern et al. (1993) pointed out, there is much disagreement about whether this is true, and if it is, what is driving women's concern. If women do become more educated in forest management, they can also pass information to their husbands and other NIPF owners which could again lead to better overall management.

Another gap in information is not within a particular group, but in information about management plans. One question that I asked every interviewee was whether they 
had a written management plan; less than one-third of landowners did. I also asked why they chose to have or not to have a management plan. Many of the landowners responded that they would not know where to get one. Given the number of landowner assistance programs in Michigan, I did not expect so many landowners would be unaware as to who could help them write a management plan and their benefits. It seems as though government agencies are not actively communicating with landowners about the importance of good forest management.

All in all, there were several areas where information was lacking. In order to reach the goals of maintaining forested land and a consistent timber supply, state and federal agencies should undertake active recruitment for assistance programs and management information distribution. Another way to better reach NIPF owners with important information would be to improve the image of the DNR in the eyes of NIPF owners; the current view is that the DNR is not focused on helping landowners, but on interfering on their land. While that may not be the case in reality, it is the view of some of my interviewees as well as NIPF owners that participated in previous research (Jones and Finley 1993, Brook et al. 2003, Shandas 2007). The most obvious way to increase program participation and maintain forested area in the state of Michigan is to work on building trust in government agencies. Some landowners were also strongly motivated by financial incentives, so much so that they enrolled in government funded programs despite their distrust, merely for the financial benefit. Increasing the financial incentives of owner assistance programs could potentially encourage higher participation, but would not be as feasible or likely as effective as gaining the trust of NIPF owners. Another suggestion, brought up by the wife of interviewee \#5, for getting information to NIPF owners is to reinstate foresters for each conservation district. She said, "It was the single most important way for landowners to get educated." This landowner was, however, not one that did not trust the government; in fact, interviewee \#5 and his wife participated in more programs than any other interviewee. This makes it difficult to know why exactly district foresters would be more effective than other government officials, since she and her husband trusted them all. She did not say why she thought that conservation district foresters were so essential to NIPF owners, except that they conducted an initial site visit 
for free. My hypothesis is that district foresters are more visible to NIPF owners because of their small service area, so they likely get to know landowners better than officials who work for the state or federal government. This is also not a very economical solution to the issue of information distribution and program participation, but given the fact that landowners prefer speaking with foresters, particularly if they know them, it may be a good solution.

The potential implications of this research on Michigan's forested landscape depend on the actions taken by policy makers and implementers to incorporate these and similar findings into their practices. The most important finding from my research is that NIPF owners influence their neighbors' management and are influenced by their neighbors both directly and indirectly. If even a few landowners in a community received information and advice about land management and programs, the amount of actively managed forest would undoubtedly increase, particularly if those landowners were community leaders, such as private foresters. However, information and opinions that are not necessarily correct (such as distrust of government agencies and logging companies) is just as likely to spread among NIPF owner communities. Also, since landowner assistance programs require that the land not be converted from forest, greater participation would decrease forest fragmentation, benefitting wildlife and ecosystem services. Any action that results in better information reaching NIPF owners will result in more sustainable management and healthier forests in the western Upper Peninsula. 


\section{Works Cited}

Amacher GS, Conway MC, Sullivan J. 2003. Econometric analyses of nonindustrial forest landowners: Is there anything left to study? Journal of Forest Economics 9(2):137-164.

Babbie ER. 2010. The Practice of Social Research. 12th ed. Belmont, CA: Wadsworth.

Beach RH, Pattanayak SK, Yang J-C, Murray BC, Abt RC. 2005. Econometric studies of non-industrial private forest management: a review and synthesis. Forest Policy and Economics 7(3):261-281.

Bennett AF. 2003. Linkages in the Landscape: The Role of Corridors and Connectivity in Wildlife Conservation. Gland, Switzerland: World Conservation Union.

Bernard HR. 2006. Research Methods in Anthropology: Qualitative and Quantitative Approaches. 4th ed. Lanham, MD: AltaMira.

Best C, Wayburn L. 2001. America's Private Forests: Status and Stewardship. Washington D.C.: Island Press.

Beyer Jr. DE, Homan L, Ewert DN. 1997. Ecosystem management in the eastern Upper Peninsula of Michigan: A case history. Landscape and Urban Planning 38(3):199-211.

Bliss JC, Martin AJ. 1989. Identifying NIPF Management Motivations with Qualitative Methods. Forest Science 35(2):601-622.

Blumberg S, Luke J. 2010. Wireless substitution: Early release of estimates from the National Health Interview Survey, July-December 2009. National Center for Health Statistics. Atlanta, GA, Centers for Disease Control and Prevention.

Bovee J, Holley A. 2002. Planners vs non-planners: Characteristics and differences between non-industrial private forest landowners in southeastern Oklahoma who engage in planned and non-planned forest management. In Amacher GS, Sullivan J. Proceedings of the 2002 Southern Forest Economics Workshop. p. 254-267.

Brook A, Zint M, DeYoung R. 2003. Landowners' responses to an Endangered Species Act listing and implications for encouraging conservation. Conservation Biology 17(6):1638-1649. 
Butler B. 2008. Family forest owners of the United States, 2006. N. R. Station. United States Department of Agriculture Forest Service. Newton Square, PA: Northern Research Station.

Butler B. 2010. Email to author.

Chapin III FS, Zavaleta ES, Eviner VT, Naylor RL, Vitousek PM, Reynolds HL, Hooper DU, Lavorel S, Sala OE, Hobbie SE, Mack MC, Diaz S. 2000. Consequences of Changing Biodiversity. Nature 405:234-242.

Cialdini RB, Trost MR, Gilbert DT, Fiske ST, Lindzey G. 2008. Social influence: Social norms, conformity, and compliance. Handbook of social psychology 2:151-192.

Cooperative Forestry Assistance Act of 1978. Public Law 95-313, $95^{\text {th }}$ Congress, $2^{\text {nd }}$ Session, 1 July 1978.

Corbin J, Morse JM. 2003. The Unstructured Interactive Interview: Issues of Reciprocity and Risks When Dealing with Sensitive Topics. Qualitative Inquiry 9(3):335-54.

Creighton JH, Baumgartner DM, Blatner KA. 2002. Ecosystem management and nonindustrial private forest landowners in Washington State, USA. SmallScale Forestry 1 (1):55-69.

Department of Natural Resources ${ }^{2}$. 2005. Western Upper Peninsula Ecoregion. Retrieved 03 October, 2010, from http://www.dnr.state.mi.us/publications/pdfs/HuntingWildlifeHabitat/WCS/LF/W UP_overview.pdf

Department of Natural Resources. 2008. Commercial Forest Summary. Retrieved 16 February, 2011, from http://www.michigan.gov/documents/dnr/IC4171_CommercialForestSummary_1 85969_7.pdf

Department of Natural Resources. 2011a. Commercial Forest (CF) Information and Forms. Retrieved 16 February, 2011, from http://www.michigan.gov/dnr/0,1607,7-153-30301_30505_34240-34016-,00.html.

\footnotetext{
${ }^{2}$ The Department of Natural Resources merged with the Department of Environmental Quality, creating the Department of Natural Resources and Environment in 2009, and was split and again became the Department of Natural Resources in 2011.
} 
Department of Natural Resources. 2011c. Forest Legacy Program. Retrieved 18 February, 2011, from http://www.michigan.gov/dnr/0,1607,7-153-30301_30505_3424099280--,00.html.

Department of Natural Resources. 2011d. Forest Stewardship Program. Retrieved 18 February, 2011, from http://www.michigan.gov/dnr/0,1607,7-153-30301_30505107504--,00.html.

Department of Natural Resources. 2011b. Qualified Forest Property. Retrieved 18 February, 2011, from http://www.michigan.gov/dnr/0,1607,7-15330301_30505_34240-164332--,00.html.

DeWalt KM, DeWalt BR. 2002. Participant Observation: a Guide for Fieldworkers. Walnut Creek, CA: AltaMira.

Dillman DA. 1978. Mail and Telephone Surveys: The Total Design Method. 1st ed. New York, NY: John Wiley \& Sons.

Dimitri C, Effland A, Conklin N. 2005. The 20th Century Transformation of U.S. Agriculture and Farm Policy. Economic Research Service, United States Department of Agriculture.

Economic Research Service. 2008. 2008 Farm Bill: Side-by-Side. Retrieved February 18, 2011, from http://www.ers.usda.gov/FarmBill/2008/.

Erickson DL, Ryan RL, De Young R. 2002. Woodlots in the rural landscape: landowner motivations and management attitudes in a Michigan (USA) case study. Landscape and Urban Planning 58:101-112.

Federal Agricultural Improvement and Reform Act of 1996. Public Law 104-127, $104^{\text {th }}$ Congress, $2^{\text {nd }}$ Session, 4 Apr. 1996.

Finley AO, Kittredge DB, Stevens TH, Schweik CM, Dennis D. 2006. Interest in crossboundary cooperation: identification of distinct types of private forest owners. Forest Science 52(1):10-22.

Food, Agriculture, Conservation, and Trade Act of 1990. Public Law 101-624, $101^{\text {st }}$ Congress, $2^{\text {nd }}$ Session, 28 Nov. 1990.

Forest Service. 2008c. Forest Legacy Program. Retrieved 18 February, 2011, from http://www.fs.fed.us/spf/coop/programs/loa/aboutflp.shtml.

Forest Service. 2008b. Major Findings from the U.S. Forest Service, National Woodland Owner Survey. Family Forest Research Center. Amherst, MA: Department of Agriculture. 
Forest Service. 2008a. National Woodland Owner Survey. Forest Inventory and Analysis Program. Amherst, MA: Department of Agriculture.

Forest Service. 2009. Forest Stewardship Program National Standards and Guidelines. Retrieved 19 February, 2011, from http://www.fs.fed.us/spf/coop/programs/loa/fsp.shtml.

Forest Service. 2010. Forest Stewardship Program. Retrieved 18 February, 2011, from http://www.fs.fed.us/spf/coop/programs/loa/fsp.shtml.

Forest Service. 2011. Total Summary of Northeastern Area Projects Completed. Retrieved 18 February, 2011, from http://www.na.fs.fed.us/legacy/.

Froese R, Hyslop M, Miller C, Garmon B, McDiarmid H, Shaw A, Leefers L, Lorenzo M, Brown S, Shy M. 2007. Large-tract Forestland Ownership Change: Land Use, Conservation, and Prosperity in Michigan's Upper Peninsula. Working paper. National Wildlife Federation. Web. 03 Oct. 2009. $<\mathrm{http}: / /$ www.mecprotects.org/UP_forest_ownership_change.pdf $>$.

Gan J, Kolison Jr. SH, Tackie NO. 2003. African-American Forestland Owners in Alabama's Black Belt. Journal of Forestry 101(3):38-43.

Gray RL, Teels BM. 2006. Wildlife and Fish Conservation through the Farm Bill. Wildlife Society Bulletin 34(4):906-913.

Gustafson EJ, Loehle C. 2008. How will the Changing Industrial Forest Landscape Affect Forest Sustainability? Journal of Forestry 106(7):380-387.

Hansen AJ, Knight RL, Marzluff JM, Powell S, Brown K, Gude PH, Jones K. 2005. Effects of Exurban Development on Biodiversity: Patterns, Mechanisms, and Research Needs. Ecological Applications 15(6):1893-1905.

Haymond JL. 1988. NIPF Opinion Leaders: What Do They Want? Journal of Forestry 86(4):30-31, 34-35

Hodgdon B, Cusack C, Tyrrell M. 2007. Literature review: An annotated bibliography on family forest owners. GISF Research paper 001-R. Yale University, School of Forestry and Environmental Studies, Global Institute of Sustainable Forestry.

Hujala T, Pykalainen J, Tikkanen J. 2007. Decision making among Finnish nonindustrial private forest owners: The role of professional opinion and the desire to learn. Scandinavian Journal of Forest Research 22:454-463. 
Irland LC. 1994. Getting from here to there: Implementing ecosystem management on the ground. Journal of Forestry 92(8):12-17.

Jacobson M, Jones E, Cubbage F. 1996. Landowner attitudes toward landscape-level management. In: Baughman, MJ. Symposium on Nonindustrial Private Forests: Learning from the Past, Prospects for the Future. St. Paul, MN: University of Minnesota. p.417-425.

Jarrett A, Gan J, Johnson C, Munn IA. 2009. Landowner awareness and adoption of wildfire programs in the southern United States. Journal of Forestry 107(3):113118.

Johnson R, Becker GS, Capeheart T, Chite RM, Cowan T, Gorte RW, Hanrahan CE, Jurenas R, Monke J, Rawson JM, Schnepf R, Richardson J, Marples DJ, Jickling M, Weiss NE. 2008. The 2008 Farm Bill: A Summary of Major Provisions and Legislative Action. Congressional Research Service, United States Library of Congress.

Jones SB, Luloff AE, Finley JC. 1995. Another look at NIPFs: facing our myths. Journal of Forestry 93(9):41-44.

Jones S, Finley JC. 1993. Public forest stewardship ethic: Extension's role in the forest program. Journal of Extension 31(3):8-10.

Joshi S, Arano K. 2009. Determinants of private forest management decisions: A study on West Virginia NIPF landowners. Forest Policy and Economics 11(2):118-125.

Kuuluvainen J, Karppinen H, Ovaskainen V. 1996. Landowner objectives and the nonindustrial private timber supply. Forest Science 42(3):300-309.

Leatherberry EC, Kingsley NP, Birch TW. 1998. Private Timberland Owners of Michigan, 1994. United States Department of Agriculture Forest Service. St. Paul: North Central Forest Experiment Station.

Lee R. 2004. Recording Technologies and the Interview in Sociology, 1920-2000. Sociology 38(5):869-889.

Lee RM, Renzetti CM. 1990. The Problems of Researching Sensitive Topics: An Overview and Introduction. American Behavioral Scientist 33(5):510-528.

Loyland K, Ringstad V, Oy H. 1995. Determinants of forest activities—a study of private nonindustrial forestry in Norway. Journal of Forest Economics 1(2): 219-238. 
Matta J, Alavalapati J, Tanner G. 2007. A framework for developing marked-based policies to further biodiversity on non-industrial private forests (NIPF). Forest Policy and Economics 9(7):779-788.

McClennen N, Wigglesworth RR, Anderson SH. 2001. The effect of suburban and agricultural development on the activity patterns of coyotes (Canis latrans). American Midland Naturalist 146:27-36.

Mehmood S, Zhang D. 2001. Forest parcelization in the United States: a study of contributing factors. Journal of Forestry. 99(4):30-34.

Mohai P. 1992. Men, women, and the environment: an examination of the gender gap in environmental concern and activism. Society and Natural Resources. 5(1):1-19.

Nagubadi V, McNamara KT, Hoover WL, Mills jr. WL. 1996. Program participation behavior of non-industrial forest landowners: A probit analysis. Journal of Agricultural and Applied Economics 28(2):323-336.

Natural Resources Conservation Service. 2006. State Wildlife Habitat Incentives Program (WHIP) for Michigan. Retrieved February 18, 2011, from http://www.mi.nrcs.usda.gov/programs/whip.html.

Natural Resources Conservation Service. 2009. Fact Sheet: Environmental Quality Incentives Program. Retrieved February 18, 2011, from http://www.nrcs.usda.gov/programs/eqip/index.html\#who.

Natural Resources Conservation Service. 2010b. Fact Sheet: Conservation Stewardship Program. Retrieved 19 February, 2011, from http://www.nrcs.usda.gov/programs/new_csp/csp.html.

Natural Resources Conservation Service. 2010c. Michigan Ranking Pools and Priority Resource Concerns. Retrieved 18 February, 2011, from http://www.mi.nrcs.usda.gov/programs/csp.html.

Natural Resources Conservation Service. 2010a. Wildlife Habitat Incentive Program. Retrieved 19 February, 2011, from http://www.nrcs.usda.gov/programs/whip/.

Natural Resources Conservation Service. 2011a. Environmental Quality Incentives Program. Retrieved 18 February, 2011, from http://www.nrcs.usda.gov/programs/eqip/index.html\#who.

Natural Resources Conservation Service. 2011b. Michigan Wildlife Habitat Incentives Program (WHIP) General Information for FY 2011. Retrieved 19 February, 2011, from http:/www.mi.nrcs.usda.gov/programs/whip.html. 
Nelson FJ, Schertz LP. 1996. Provisions of the Federal Agriculture Improvement and Reform Act of 1996. Economic Research Service, United States Department of Agriculture.

Newman DH, Aronow ME, Harris jr. TG, Macheski G. 1996. Changes in timberland ownership characteristics in georgia. In: Baughman MJ. Symposium on Nonindustrial Private Forests: Learning from the Past, Prospects for the Future. St. Paul, MN: University of Minnesota. p.214-221.

Potter-Witter K. 2005. A cross-sectional analysis of Michigan nonindustrial private forest landowners. Northern Journal of Applied Forestry 22(2):132-138.

Potter-Witter, K. 2008. Qualified Forest Property Tax Program. Online Publications by MSU's Department of Forestry and Extension. Michigan State University Extension. Web. 18 Feb. 2011. $<$ http://forestry.msu.edu/extension/extdocs/facts32.pdf $>$.

Quinn T. 1997. Coyote (Canis latrans) habitat selection in urban areas of western Washington via analysis of routine movement. Northwest Science 71:289-297.

Rickenbach M, Bliss J, Reed S. 2004. Collaboratives, cooperation, and private forest ownership patterns: implications for voluntary protection of biological diversity. Small Scale Forest Economics, Management and Policy 3(1):69-84.

Rickenbach M, Kittredge D. 2009. Time and distance: comparing motivations among forest landowners in New England, USA. Small-Scale Forestry 8(1):95-108.

Rickenbach M, Reed A. 2002. Cross-boundary cooperation in a watershed context: The sentiments of private forest landowners. Environmental Management 30(4):584594.

Rickenbach M, Zeuli K, Sturgess-Cleek E. 2005. Despite failure: The emergence of "new" forest owners in private forest policy in Wisconsin, USA. Scandinavian Journal of Forest Research 20(6):503-513.

Rogers E, Shoemaker F. 1971. Communication of innovations: A cross-cultural approach. The Free Press. New York.

Romm J, Tuazon R, Washburn C. 1987. Relating forestry investment to the characteristics of nonindustrial private forestland owners in northern California. Forest Science 33(1):13.

Salmon O, Brunson M, Kuhns M. 2004. Benefit-based audience segmentation: a tool for identifying non-industrial private forest (NIPF) owner education needs. Journal of Forestry 104(8):419-425. 
Saunders DA, Hobbs RJ, Margules CR. 1991. Biological consequences of ecosystem fragmentation: A review. Conservation Biology 5(1):18-32.

Schaaf K, Broussard S. 2006. Private forest policy tools: A national survey exploring the American public's perceptions and support. Forest Policy and Economics 9(4): 316-334.

Schaaf K, Broussard S, Hoover WL. 2004. Private lands in the Midwest: Exploring landowner views on collaboration, community, and social capital. Human Dimensions of Family, Farm, and Community Forestry International Symposium, Pullman, WA: Washington State University.

Schmiegelow F, Mönkkönen M. 2002. Habitat loss and fragmentation in dynamic landscape: avian perspectives from the boreal forest. Ecological Applications 12(2):375-389.

Shandas V. 2007. An empirical study of streamside landowners' interest in riparian conservation. Journal of the American Planning Association 73(2):173-184.

Stern PC, Dietz T, Kalof L. 1993. Value orientations, gender, and environmental concern. Environment and Behavior 25(5):322-348.

Stevens T, White S, Kittredge DB, Dennis D. 2002. Factors affecting NIPF landowner participation in management programs: a Massachusetts case study. Journal of Forest Economics 8:169-184.

Stordal S, Lien G, Baardsen S. 2008. Analyzing determinants of forest owners' decisionmaking using a sample selection framework. Journal of Forest Economics 14(3): $159-176$.

Sun X, Sun C, Munn IA, Hussain A. 2009. Knowledge of three regeneration programs and application behavior among Mississippi nonindustrial private forest landowners: A two-step sample selection approach. Journal of Forest Economics 15(3):187-204.

Swift T, Hannon S. 2010. Critical Thresholds Associated with Habitat Loss: A Review of the Concepts, Evidence, and Applications. Biological Reviews 85(1):35-53.

Voukon M, Amacher G, Wear DN. 2006. Scale of harvesting by non-industrial private forest landowners. Journal of Forest Economics 11(4):223-244.

U.S. Census Bureau. 2009. Homes with cell phones nearly double in first half of decade. Public Information Office. Washington D.C., U.S. Census Bureau. 
West PC, Fly JM, Blahna DJ, Carpenter EM. 1988. The Communication and Diffusion of NIPF Management Strategies. Northern Journal of Applied Forestry 5(4):265-270.

Wilcove DS, Rothstein D, Dubow J, Phillips A, Losos E. 1998. Quantifying Threats to Imperiled Species in the United States: Assessing the relative importance of habitat destruction, alien species, pollution, overexploitation, and disease. BioScience 48(8):607-615.

Womach J. 2005. Agriculture: A Glossary of Terms, Programs, and Laws. Congressional Research Service. Washington D.C., United States Library of Congress. 


\section{Appendix A: Preliminary Interview Questions}

1. How long have you owned your property?

2. How did you acquire your property? [Did you buy your property or inherit it?]

3. Is your forest property your primary residence? If not, is it your secondary residence? How far from your primary residence is your forest property?

4. Can you please describe your property? [how many acres, how much forest, what kind of forest]

5. Some people work with their land to achieve certain goals, such as improved timber or wildlife habitat. Do you actively work with [or manage] your land? How?

6. Do you have a written management plan?

7. What are your management goals?

8. Is your forest enrolled in any programs [like CFA, timber improvement, conservation easement]? If so, which programs? Why did you choose to enroll?

9. How many neighboring forest owners do you know personally? ${ }^{3}$

10. Do you know how your neighbors manage their land? Do your neighbors manage similarly to you? If not, what is different about the way they manage their land?

11. Do you talk to your neighbors about what you do with your land? For example, do you talk about what is successful and what doesn't work?

12. Have you ever managed or avoided managing in a certain way because your neighbors had success or failure with that method?

13. Have you ever managed or avoided managing in a certain way because your neighbors had success or failure with that method?

14. Where do you get advice about managing your land? For example, do you talk with a forester or someone from the DNR? What source do you use most?

15. Do you have any neighbors that recently purchased their land or neighbors that don't live near their land?

\footnotetext{
${ }^{3}$ The first six preliminary interviewees were not asked question 9 .
} 
16. Do you plan to sell or give away all or part of your land in the next ten years?

17. Are there any neighbors that you think would be interested in being interviewed or that would be valuable for me to interview?

18. What is your age and highest level of education? ${ }^{4}$

${ }^{4}$ Question 18 originally asked interviewees for their income, but that portion of the question was dropped early in the interviewing process due to low response. 


\section{Appendix B: Main Sample Interview Questions}

1. How long have you owned your property? Do you own more than one forested property?

2. How did you acquire your property? [Did you buy or inherit it?] Why did you purchase a forested property?

3. Do you live on your forest property for most of the year? [Where do you live if not? How far is your home from your forest property?]

4. Can you please describe your property? [how many acres, how much forest, what kind of forest?]

5. Some people work with their land to achieve certain goals that they manage for [such as timber improvement, wildlife habitat]. What are your goals, if any? Do you actively work with or manage your land? What do you do and why? Why or why not?

6. Do you have a written management plan [a plan stating what you want to do with your land and how you will achieve it]? Why or why not? Can you describe your plan?

7. Is your forest enrolled in any programs [for example CFA, conservation easements]? If so, which program? Why did you choose to enroll? What do you see as the benefits or drawbacks to these programs?

8. Do you know how your neighbors manage their land? Do your neighbors manage their forest similar to the way you do? If not, what is different about what they do to their land?

9. How many neighboring landowners do you know?

10. Do you talk to your neighbors about what you do with your land? If so, what do you talk about? If not, why not?

11. Have you ever specifically done or avoided something because of your neighbor's success or failure with that method? If so, what was it? Why did you do it?

12. Where do you get advice about managing your land? [for example forester, DNR, other owners, internet] Why did you choose that source? What kind of advice have you received? 
13. Are there any neighbors that you think would be interested in being interviewed or that could give me valuable information? If so, could you please tell me their name and possible a way to contact them?

14. Could you please tell me your age and highest level of education? 